\title{
Narracje litotyczne w wielkiej narracji teatru antropologicznego na przykładzie pracy Teatru Węgajty/Projektu Tere- nowego w Domu Pomocy Spotecznej w Jonkowie
}

\author{
Kamila Paprocka
}

\begin{abstract}
Abstrakt: Artykuł stanowi fragment mojej pracy magisterskiej Narracje litotyczne w wielkiej narracji teatru antropologicznego na przykładzie pracy Teatru Węgajty/Projektu Terenowego. Analizuję w nim możliwości teatru antropologicznego poprzez pokazanie elementów, które legły u jego podstaw: fascynacji kulturą tradycyjną oraz pracy w lokalnej wspólnocie. „Wielka narracja” teatru antropologicznego zastąpiona zostaje „małą narracją” „teatru potrzebnego”, wywodzącą się z wykluczonych, zapomnianych litot. Artykuł dokumentuje i analizuje tzw. teatr potrzebny na przykładzie działań Teatru Węgajty/Projektu Terenowego w Domu Pomocy Społecznej w Jonkowie.

Wyrażenia kluczowe: narracja litotyczna, wielka narracja, mała narracja, teatr antropologiczny, Teatr Węgajty
\end{abstract}

\section{MIMESIS I, CZYLI HISTORIE (JESZCZE) NIEOPOWIEDZIANE}

„Czy nie porzucając codziennego doświadczenia, nie jesteśmy skłonni widzieć $\mathrm{w}$ takim łańcuchu epizodów naszego życia

historii (jeszcze nieopowiedzianych), historii, które domagają się, by je opowiedzieć, historii dających opowieści punkty zakotwiczenia?"

P. Ricoeur, Intryga i historyczna opowieść (Ricoeur, 2008a, s. 110)

Mieszkańców Domu Pomocy Społecznej (dalej: DPS) w Jonkowie spotkałam, obserwując pracę teatralną Teatru Węgajty/Projektu Terenowego w latach 2008-2011. Skutkiem tego spotkania były przeprowadzone z nimi wywiady. Chciałam za ich sprawą przede wszystkim poznać pensjonariuszy, okazać im zainteresowanie, a także poprzez nawiązanie bliskiej relacji zebrać informacje na temat ich biografii. Czasem byli to losowo wybrani mieszkańcy, czasem tacy, na których zwracali uwagę liderzy Teatru: Erdmute i Wacław Sobaszkowie oraz personel DPS w Jonkowie. Starałam się zwracać uwagę również na tych, którzy byli najmniej widoczni i aktywni, z dużym stopniem niesprawności i, jak się okazało, sporymi kłopotami z pamięcią. Dlatego moi rozmówcy dzielą się na tych, którzy biorą aktywny udział w pracy teatralnej, i na tak zwany drugi plan - obserwatorów 
tej pracy, najczęściej ludzi całkowicie niepełnosprawnych. Moja praca początkowo miała związek z działaniami animacyjnymi Teatru Węgajty w DPS, mieszczącymi się w programie teatru potrzebnego. Stopniowo zaczęłam prowadzić własne poszukiwania. Interesowało mnie, na ile potańcówka, którą organizuje Teatr, przypomina pensjonariuszom ich potańcówkę z młodości; badałam, czym jest dla nich śmierć i jak radzą sobie ze świadomością odejścia. Kiedy - w dużej mierze dzięki moim badaniom - powstał pierwszy spektakl z udziałem mieszkańców DPS, zaczęło mnie interesować, jak rozumieją to doświadczenie i w jaki sposób wpływa ono na życie codzienne w domu i panujące tam relacje. Śledziłam dynamikę tego procesu, przyglądając się pracy teatralnej w DPS w Jonkowie podczas powstawania trzech spektakli.

Z moich obserwacji funkcjonowania DPS w Jonkowie wynika ${ }^{1}$, że jego personel przyjął rolę „zwierzchników”, którzy odbierają prawo do własnej definicji sytuacji „podwładnym” posiadającym - zdaniem „zwierzchników” - niepełny, a co za tym idzie, nieprawdziwy obraz rzeczywistości (Becker, 1971). Tę prawidłowość w polskich domach pomocy społecznej zauważyła Agnieszka Kumaniecka-Wiśniewska, badając tożsamość kobiet upośledzonych umysłowo przebywających w ośrodkach opiekuńczych (Kumaniecka-Wiśniewska, 2006). Bliskie jest mi doświadczenie, które spotkało socjolożkę podczas jednej z konferencji, na której obecni byli pracownicy socjalni. Referując sytuację kobiet upośledzonych umysłowo w domach pomocy społecznej (z perspektywy ich pensjonariuszek), spotkała się ze strony pracowników socjalnych z zarzutem nierzetelności i stronniczości w badaniach. Mnie pouczyła dyrektorka DPS w Jonkowie: twierdząc, że „mieszkańcy mówią różne rzeczy”, wyraźnie postawiła się w roli jedynego źródła „prawdy” i zanegowała sens poszukiwania tej „prawdy” w narracjach mieszkańców DPS.

Powodem ataku i na mnie, i na doktor Kumaniecką-Wiśniewską było zakwestionowanie potrzeby przedstawienia obrazu domu pomocy społecznej z perspektywy mieszkających tam ludzi. Zarówno dyrektorka, jak i wspomniani przez Kumaniecką pracownicy socjalni posługiwali się takimi kategoriami, jak „prawda” i „obiektywna wiedza”, traktując siebie jako jedynych dysponentów owej „wiedzy” i twierdząc, że upośledzenie czy choroba badanych nie legitymują ich do rozmowy z kimś z zewnątrz, a tym bardziej do wypowiedzi na temat DPS. Dyrektorka podkreślała, że w DPS jest zaledwie kilkanaście osób, z którymi „można rozmawiać”; pozostali się do tego nie nadają, bo są „niesprawni” lub uniemożliwia im to choroba „niesomatyczna”. W ujarzmiającej i dyscyplinującej instytucji, jaką jest DPS, wiedza równa się władzy. Kluczowe znaczenie dla pracowników socjalnych ma nie pensjonariusz, lecz choroba, która go definiuje.

Sytuacja, z którą się spotkałam, sprawiła, że nie mogłam patrzeć na DPS inaczej niż jak na instytucję totalną. Tym ciekawsze wydało mi się zbadanie, jak w ramach takiej instytucji działać może teatr znany ze strategii rozbijania tego typu struktur. To także umocniło we mnie wiarę w sens i siłę narracji „podwładnych”, „wykluczonych” i „upośledzonych”.

1 Z uwagi na ograniczone miejsce nie zmieścił się tutaj szczegółowy opis funkcjonowania tej instytucji, powstały na podstawie moich obserwacji. 
Tematem tego artykułu są przede wszystkim „małe opowieści” mieszkańców, które wyłoniły się z wywiadów. Są one krótkie i urywane, o dość nieregularnej narracji. $\mathrm{Na}$ ich znikomy kształt złożyły się z pewnością kłopoty rozmówców ze zdrowiem, zwłaszcza z pamięcią, jednak nie tylko. Drugi powód jest natury egzystencjalno-filozoficznej - spotkani przeze mnie ludzie nie mieli w ogóle potrzeby snucia opowieści o swoim życiu i nawet nie wiedzieli, jak się za to zabrać. Wielokrotnie stawałam bezsilna wobec mikronarracji, których wysłuchałam, a zarazem zainspirowana i zaciekawiona ich znikomością. Przez długi czas próbowałam doszukać się w nich inspirującego etnograficznie materiału. Starałam się dociec, czy mają ze sobą coś wspólnego. Czy jest jakaś tożsamość mieszkańca domu pomocy społecznej? Tożsamość implikuje narrację, która umożliwia nam konstrukcję autobiografii - ale czy każda narracja zakłada tożsamość? Czy przy tak dalece posuniętej niespójności tych narracji można mówić o jakiejkolwiek tożsamości? A jeśli tak, to co ją konstytuuje? Meritum tego wywodu będzie stanowić jednak to, co nieopowiadalne, a co nierozerwalnie łączy się z doświadczeniem cierpienia, biorącym się z niemożności działania i mówienia.

\section{Litotyczne narracje mieszkańców DPS}

Określenie „narracje litotyczne” pochodzi od figury retorycznej zwanej litotą. Greckie litótēs oznacza skromność, prostotę, a sama litota, będąca tropem znanym już w antycznej retoryce, „osłabia dobitność mowy i podobnie jak eufemizm łagodzi ostrość sądów; wsparta jednak szczególną intonacją czy mimiką może skuteczniej skupiać uwagę na opinii mówiącego niż w przypadku wyrażenia jej wprost" (Okopień-Sławińska, 2002, s. 286). To także „przeciwieństwo hiperboli minimalizujące wyobrażenie jakiegoś zjawiska, neutralizacja wyrazistości przedstawienia, zamierzona skromność oratorska, np. przyznanie się wobec słuchaczy do niedostatków własnej elokwencji w porównaniu z wagą i zasięgiem tematu” (Okopień-Sławińska, 2002, s. 286). „Narracja litotyczna” to coś jeszcze mniejszego niż Lyotardowska „mała narracja”. Wprowadzenie metafory „narracji litotycznej” służy w mojej pracy podkreśleniu znikomości narracji mieszkańców DPS, nieustannie starających się umniejszać samych siebie i swoje przeżycia; mówić jak najmniej, nie licząc na zainteresowanie, a raczej na to, że ich znikome doświadczenie i narracja przemkną się, pozostając niezauważone, niezarejestrowane i nieusłyszane. Paradoksalnie jednak - jak greccy retorzy - pensjonariusze DPS potrafią brakiem dobitności swej mowy skupić na sobie uwagę, a nawet zainspirować artystów do pracy teatralnej. Inspiracją do ocalenia „litotycznych narracji” mieszkańców DPS stała się dla mnie myśl Paula Ricoeura, zawarta w trzech tomach jego Czasu i opowieści (stąd zaczerpnęłam metaforę trzech mimesis) oraz w książce $O$ sobie samym jako innym, gdzie prezentuje teorię „tożsamości narracyjnej”. Narracja może być rozumiana - jak u fenomenologów - jako „ludzka zdolność do organizowania zdarzeń i działań w całościowe, rozwijające się w czasie struktury znaczące" (Rosner, 2003, s. 12). Jak pokazały przeprowadzone przeze mnie badania w DPS w Jonkowie, nie wszyscy ludzie tę zdolność posiadają. Może być też rozumiana literalnie

SLH 2/2013 | str. 150 
- jak u Ricoeura - jako słowny tekst narracyjny o zdarzeniach, fikcyjna lub historyczna opowieść, pewien kod tekstowy wypracowany przez kulturę, która z prostego następstwa zdarzeń tworzy całość znaczącą, nadaje mu rys dyskursywny. Ricoeur uważał, że odwoŁujemy się do kodów kulturowych, by stworzyć narrację, a co za tym idzie - by odnaleźć formę i sens naszego doświadczenia. Poniżej postaram się opisać, jak wykorzystywane w Teatrze Węgajty narracje literackie oraz narracja samego teatru (rozumiana jako jego historia, opowieść o nim, projekt działania, estetyka) porządkują i nadają sens „litotycznym narracjom" mieszkańców DPS.

Paul Ricoeur w Konfiguracji w opowieści fikcyjnej zwrócił uwagę na kluczowy dla fabuły - życia i literackiej - problem spójności. Spójność rozumiana jako jedność celów, przyczyn, przypadków, jak też jedność czasowa jest definicyjną cechą fabuły i metafory. Nie wyklucza dysonansu, czyli momentu nieprzewidywalności i nowości, który rozbija utarte schematy fabularne, nadając wzorcowej fabule siłę i dynamikę. Dzieje się to, kiedy uniwersalny wzorzec zostanie umieszczony w konkretnym, partykularnym czasie. Postrzeganie dekompozycji i dysonansu stanowi podstawową różnicę między strukturalistami i przedstawicielami narratologii a Ricoeurem, który przywiązywał wagę do rozumienia odbywającego się wieloetapowo, z kluczowym momentem, jakim jest przeniknięcie się narracji z horyzontem czytelnika.

Poniżej zajmę się zatem badaniem tożsamości narracyjnej mieszkańców DPS i spójności ich doświadczenia, które w celu uporządkowania mojego wywodu (podążającego za koncepcją trzech mimesis) nazwałam mimesis I: „prostym następstwem zdarzeń”, tym, co jeszcze narracją nie jest, ale zakłada jej istnienie. Zanim bowiem wejdę do „królestwa fikcji”, jakim jest ubranie doświadczenia mieszkańców DPS w „wielkie opowieści” literackie, koniecznie trzeba przedstawić „przedrozumienie” ich świata działania. Z analizy wywiadów swobodnych, zarówno w aspekcie spójnościowym, jak i podkreślającym rozbicie i niespójność, wyłoniły się portrety pensjonariuszy DPS w Jonkowie zawierające to, co sami chcieli o sobie powiedzieć. To, co nie zostało powiedziane, również jest znaczące - narracje łamią się, kiedy pojawia się wątek życia osobistego i partnerów życiowych lub podczas przywoływania epizodów, które doprowadziły do znalezienia się w DPS. W niektórych wywiadach - z Katarzyną, Filomeną, Anią, Panią Q czy Panem Y² - rzuca się w oczy brak zdolności i chęci do uchwycenia całości swojego życia w narrację. W innych (Kazimierz, Barbara) dominuje wysoki poziom konfabulacji i zmyślenia, nadmierne fikcjonalizowanie rzeczywistości, przeczące regułom prawdopodobieństwa. Podczas wywiadów poruszałam kilka zagadnień, które pomogły mi w określeniu charakteru tożsamości narracyjnej mieszkańców DPS, a mianowicie: życie w DPS, strategia przetrwania, relacja z innymi mieszkańcami DPS i bliskimi. Starałam się również wyodrębnić „wielkie narracje”, jakie pojawiają się w „litotycznych opowieściach”.

2 W celu zachowania anonimowości wszystkie imiona moich rozmówców (z wyjątkiem imion członków Teatru Węgajty) są fikcyjne. 


\section{Czas narracji}

W narracjach bohaterów czas dzieli się na ten sprzed momentu zamieszkania w DPS i ten po zamieszkaniu w DPS, obejmuje przeszłość i teraźniejszość. Najwięcej mówi się o przeszłości, kojarzonej dobrze, wręcz wybielanej. Nawiązuje ona do czasu młodości, okresu największej aktywności życiowej. Teraźniejszość jest nieciekawa - wypełniona smutkiem, samotnością, bólem, nudą. Istotną cezurą dotyczącą przeszłości jest wojna po wojnie większość mieszkańców DPS sprowadziła się w okolice Olsztyna.

Czas narracji dzieli się na okresy sprawności i postępującej niesprawności, długie miesiące rehabilitacji wypełnione pustką. Przyszłość wiąże się z odwiedzinami rodziny, przyjazdem teatru, przeniesieniem do innego ośrodka opiekuńczego. Uzależniona jest od tego, co zrobią inni („może córka mnie zabierze”) - nie posiada więc skonkretyzowanego kształtu. Najczęściej jednak związana jest z perspektywą śmierci.

\section{Miejsca}

W narracjach pojawiają się miejsca pochodzenia rozmówców: Wyszków, Warszawa, Pułtusk, Jarosław, Jeziorany, Częstochowa, Kresy Wschodnie, Susz, Wrocław. Liczne wędrówki i migracje (za pracą, partnerami życiowymi bądź w wyniku wyższej konieczności dziejowej), wraz z najważniejszą przeprowadzką na teren Warmii, czynią te miejsca ruchomymi lub utraconymi. Narracje o poszczególnych placówkach opiekuńczych i szpitalach, w których akurat było miejsce lub odpowiedni specjalista, odwzorowane są z bardzo szczegółową topografią, obfitują w nazwy ulic, numery domów i nazwiska lekarzy.

Często przywoływanym miejscem jest dom rodzinny, który zwykle jest daleko, a wspomnienie o nim budzi tęsknotę. Dom rodzinny jest elementem większego miejsca nieokreślonego precyzyjnie, które nazwałabym „to, co na zewnątrz”. Jawi się ono jako nieosiągalny cel. Dlatego przyjście kogokolwiek „stamtąd” traktowane jest jak święto. Dotarcie „tam” jest trudne, zwłaszcza dla osób z dużą niesprawnością.

\section{DPS, czyli doświadczenie krytyczne}

DPS jest tematem tabu dla jego mieszkańców. Kiedy zaczynałam temat, spotykałam się z wycofaniem i odpowiedziami: „mogę mówić o sobie, natomiast na temat DPS wolałabym nie mówić" (Iza i Katarzyna). Mieszkańcy obawiali się, że jeśli przedstawią negatywne opinie, mogą zostać ukarani przez personel. Zdarzało się, że wywiady przeprowadzałam w obecności pracownika socjalnego, po którego wyjściu mieszkaniec otwierał się i zaczynał mówić, jak jest naprawdę. Oceny te formułowano lakonicznie: „ciężkie tu mamy życie, proszę panią”, „smutne”, „nudne”, „tutaj jest do dupy”, „monotonia”. Mimo licznych wad DPS w Jonkowie wypada dobrze w porównaniu z innymi placówkami: ,jeżeli nie jestem w stanie zrobić nic, to muszę się pogodzić z tym, jak jest. Wydaje mi się, że jak 
na sytuację, jaka panuje w ogóle, to jest całkiem dobrze” (Iza i Katarzyna). Największą wartością domu jest „spokój”. Warunki mieszkaniowe oceniane są jako przyzwoite. Wadą jest natomiast brak intymności, dzielenie pokoju z innymi, wystawianie własnej choroby i kalectwa na widok innych, obcych ludzi. W kilku opiniach pojawiają się narzekania na wyżywienie oraz brak należytej opieki, trzeba bowiem „czekać, uzbroić się w cierpliwość”, „trzeba być wyrozumiałym” (Dominik). Przede wszystkim jednak „tu nie jest jak w domu” (Dominik). Pytałam również, co musiałoby ulec zmianie, żeby było lepiej. Wskazywano na dyrektorkę, którą niektórzy nazywają „pryncypałką” i która „przez pięć lat bardzo się zmieniła. W ogóle się nie interesuje tym, co się z nami dzieje. [...] Traktuje ten dom jak własny folwark. [...] Ona była kiedyś lepsza, ale od kiedy zamknęła się w kurniku, stała się okropna. Jak gdzieś wyjeżdżamy, zachowuje się tak, jakby się nas wstydziła” (Artur). O terapii mieszkańcy nie wspominają, nie wskazują też na żadne aktywizujące ich dziaŁania; mówią wręcz: „Oni myślą, że my starzy nic już nie zrobimy” (Kazimierz). Niektórzy nazywają personel i terapeutów „ludźmi od zabawiania towarzystwa” (Artur). Celem jest to, żeby przetrwać codzienność w DPS. Nie oznacza to identyfikacji z tym miejscem, a jedynie chęć ułożenia sobie życia po swojemu. Wieloma mieszkańcami kieruje wygodnictwo: „Nie chciało mi się ani gotować, ani sprzątać, ani prać. [...] Leniwy się zrobiłem po prostu. [...] Nic nie muszę robić. Tylko się wykąpać, ogolić i przebrać. [...] A tutaj robią wszystko. Oddajesz pranie, a oni przynoszą wszystko czyściutkie, poskładane” (Artur).

Zakończenie opowieści pensjonariuszy DPS stanowi pobyt w domu pomocy społecznej - należy go rozumieć poprzez następstwo epizodów, które do niego doprowadziły. Oto właściwy temat, puenta i sens ich opowieści. Moi rozmówcy mieli potrzebę wytłumaczenia, dlaczego znaleźli się w tym, a nie innym miejscu, dlaczego poddali się niemożności działania i cierpieniu. Ten krytyczny epizod łączy się z pozostałymi - rzadko jest efektem jednego doświadczenia: jest to raczej zespół epizodów, które złożyły się na obecną sytuację. Często takim zdarzeniem jest choroba lub wypadek, które spowodowały długotrwałe unieruchomienie, niepełnosprawność fizyczną, załamanie psychiczne i uniemożliwiły dalszą pracę. Epizody chorobowe są pamiętane bardzo wyraźnie, ze szczegółami. Moi bohaterowie opisujący kolejne etapy chorób i postępujące inwalidztwo próbowali nie poddać się im, ale w walce doświadczyli przegranej. Innym powodem znalezienia się w DPS jest rozpad relacji z bliskimi, zwłaszcza z partnerami życiowymi, wywołany niepowodzeniem w związku albo śmiercią współmałżonka. Choroba miała często kluczowy wpływ na te stosunki, bowiem bliscy nie byli w stanie zapewnić specjalistycznej opieki. Jak mówi Iza: „Wiem, że czynności, jakie powinny być wykonywane przy mnie, będą wykonywane na pewno. Bez stresu, czy to będzie, czy się na pewno zdąży. Mnie nie chodzi o takie sprawy, jak nakarmienie, ubranie, tylko np. o wstawanie w nocy, o przekręcanie mnie z boku na bok. Żebym nie musiała nikogo wybudzać, żeby robił to w nocy. Bo czasem dwa razy trzeba kogoś wybudzać. W domu to różnie było. Ja się wybudziłam, wołaŁam, później był kłopot z zaśnięciem itd. To podstawowy powód, dla którego znalazłam się tutaj. Chodziło przede wszystkim o noce, tylko o noce". 
Jak widać, pobyt w DPS wiąże się z czynnikami zewnętrznymi, na które bohaterowie narracji nie mieli wpływu. W kontekście narracji życiowej można je określić jako „okoliczności działania” (Ricoeur, 2008a, s. 86), czyli czynniki niezależne od działających podmiotów, które ograniczają ich możliwości i mają znaczący wpływ na kierunki, a zarazem skutki ich działań. Czasem są one na tyle paraliżujące, że rodzą niemożność działania, czyli cierpienie. Przebieg działania i kształt okoliczności nie mogą być prefigurowane.

\section{Strategie i taktyki przetrwania}

Wszelkie „efekty uboczne” przebywania w DPS, czyli nuda, smutek, brak intymności, monotonia, złe traktowanie, kontrola, a jednocześnie świadomość skazania na przebywanie w tym miejscu, wymagają wypracowania modelu funkcjonowania, który pozwoli zachować choć odrobinę samodzielności, zdolności i świadomości samostanowienia, własnej przestrzeni. Konieczne dla pensjonariuszy jest więc stosowanie „sposobów działania”, „strategii” i „taktyk” w ramach ich „praktyk codziennych” związanych z życiem w DPS (Certeau, 2008). „Strategie” w odróżnieniu od „taktyk” w modelu Michela de Certeau utrzymują relacje ze wspierającą je władzą. Strategia przetrwania mieszkańców DPS wiąże się z tym, co zapewnia im personel, czyli zaspokojeniem podstawowych potrzeb biologicznych i rehabilitacją. „Strategie” wdrażane są między godziną 8.00 a 15.00, w czasie pracy biura. Kiedy dyrektorka opuszcza swój gabinet, przychodzi czas stosowania „taktyk”: „wtedy towarzystwo hulaj dusza! Wtedy plener sobie robimy” (Artur). Michel de Certeau nie definiuje taktyk, opisuje je jedynie poprzez wskazanie konkretnych ludzkich aktywności: w języku odpowiadają im żarty, własny język tworzony na podstawie poprawnego i oficjalnego, a w życiu - proces czytania, ulice wypełnione przechodniami aktywnie wpływającymi na otaczającą przestrzeń. Oglądanie telewizji, słuchanie radia, muzyki, czytanie książek, rozwiązywanie krzyżówek, przeglądanie Internetu, wyjścia do centrum Jonkowa, zaangażowanie w zawody sportowe dla niepełnosprawnych, realizowanie życiowych pasji - te wszystkie drobne aktywności pozwalają „wynaleźć codzienność” DPS. Oto „taktyka” jednego z mieszkańców: „Jak wszystko śpi, pan [Artur] o ósmej wieczorem bierze kanapki, kubek, idzie na świetlicę. Siedzę tak do 2.00 nad ranem jak dobry program jest" (Artur). Pani Iza, chociaż nie może poruszać rękami, doskonale radzi sobie z komputerem - ma specjalny zestaw, który umożliwia dawanie poleceń głosowych. Dzięki Arturowi DPS w Jonkowie zajmuje siódme miejsce w zawodach tenisa stołowego. Kazimierz, dla którego szycie zawsze było pracą, a zarazem pasją, trzyma w swoim pokoju maszynę i dalej szyje. Pokój Gerwazego zastawiony był rzędami drewnianych figurek, które sam rzeźbił. Pensjonariuszy przy życiu utrzymuje także „to, co na zewnątrz": rodzina, gospodarka, praca teatralna. Pomaga im w tym mądrość i zdobyte w ciągu życia doświadczenie [„A człowiek stary więcej wie, niż oni wszyscy” (Kazimierz)] oraz zachowanie samodzielności i własnego terytorium działania: pieniądze, którymi dysponują, własne jedzenie. Jedną ze skuteczniejszych „taktyk”, której omówieniem zajmę 
się w dalszej części artykułu, jest praca teatralna organizowana w DPS przez Teatr Węgajty/Projekt Terenowy.

\author{
Śmierć \\ „Przedwczesna żałoba jako zjawisko odrzucenia przez instytucję, \\ z góry zamyka ich w kostnicy" \\ M. de Certeau, Wynaleźć codzienność
}

(Certeau, 2008, s. 191)

Motyw śmierci pojawia się w narracjach mieszkańców DPS w dwojakim charakterze. $Z$ jednej strony jest to opis obyczajów związanych ze śmiercią dawniej i obecnie oraz doświadczeń śmierci innych, najbliższych (partnerów, dzieci, rodziców). Z drugiej strony pensjonariusze opowiadają o swoim stosunku do śmierci dzisiaj, kiedy stała się wszechobecna i muszą ją oglądać niemal na co dzień: „Obserwuję naszych mieszkańców. Niektórzy nawet się nie zastanawiają, że jeszcze krok i przejdą w inny wymiar. Tak samo jak pani czeka w sklepie, żeby jak najszybciej kupić jakiś towar. Tutaj się nic nie kupuje - tylko czeka, aż biała przyjdzie" (Gerwazy). Personel DPS traktuje ich, jakby już nie żyli, zmuszając do odpoczynku czy snu i dowartościowując tych, którzy są spokojni i nieruchomi. Na początku pobytu „w trupiarni”, jak niektórzy nazywają DPS i inne ośrodki opiekuńcze, ciężko było im się z nią oswoić: „A później jak do Leszna pojechałem, tam się załamaŁem. Dlaczego? Bo tam było około 50 osób i przez siedem i pół miesiąca czułem się tak, jakbym był w trupiarni. Bo tam 30 osób zmarło. Były takie wypadki nieraz w tygodniu, że rano kobieta poszła do Piotra, a wieczorem mężczyzna. I nowych przywozili” (Dominik). Z czasem przychodzi jednak moment oswojenia, o czym świadczy fakt, że mogą o tym mówić, oraz to, że chcą wrócić do miejsc z wysoką umieralnością, bo ważniejsza jest dla nich dobra opieka. Do śmierci mają już niemal „praktyczny” stosunek. Rozumieją, że człowiek nie jest niezastępowalny: „Teraz na mszy będzie jej na pewno brakowaŁo. Chociaż ktoś pewnie zastąpi. Pani Maria to była trochę jak organista - odpowiadała księdzu, wtórowała, prowadziła. Ale przeszła już te swoje $90 \mathrm{~km}$. I jak każdego to czeka - odeszła z tego świata" (Gerwazy). Zwłaszcza że kiedy ktoś umiera, zajmuje się tóżko po nim w pokoju lub sali szpitalnej: „Było tam tak, że na terenie domu samochód przejechał pijanego, takiego Mariana, po dwóch tygodniach, jak tam byłem. Potem przerzucili mnie do pokoju na miejsce tamtego, co go samochód przejechał" (Dominik). Oswojenie przechodzi czasem wręcz w ulgę i radość: „Jak ja bym umarł, to wcale bym nie chciał, żeby ktoś po mnie płakał. Ludzie powinni się cieszyć, że już człowiek przeszedł w inny wymiar" (Gerwazy).

Najwięcej na temat śmierci opowiedział mi Gerwazy, który odszedł z grona pensjonariuszy DPS w listopadzie 2011 roku.

SLH 2/2013 | str. 155 
Trajektorie życia mieszkańców DPS obfitują w traumatyczne wydarzenia, jakie doprowadziły do rozpadu ich tożsamości osobowych, które ciężko im teraz zrekonstruować. Ich przypadek udowadnia, że tożsamość nie jest dana raz na zawsze i że nie posiada ciągłości psychologicznej - jak chciał Alasdair Maclntyre (Maclntyre, 1996). W narracjach mieszkańców DPS nie istnieje żaden z analizowanych przez Charlesa Taylora kontekstów tożsamości (Taylor, 1996, s. 10): brak wyraźnego samookreślenia, rysów tożsamości osobistej i grupowej - generalnie ciężko wyodrębnić w nich wyraziste identyfikacje.

Z pomocą przychodzi koncepcja tożsamości osobowej Paula Ricoeura, której składnik zwany ipse pozwala na zmienność w czasie i nie wymaga „niezmiennego jądra osobowości" (Ricoeur, 2003, s. 8). Gdyby tożsamość składała się tylko z idem, brak u tych ludzi wyraźnych trwałych właściwości, zwłaszcza „niezawodnego kryterium tożsamości”, jakim jest pamięć, skazywałby ich na bycie nikim, ale Ricoeurowskie ipse pozwala na to, że „nie będąc czymś, podmiot jako ten-który-jest-sobą nie jest również niczym” (Ricoeur, 2003, s. XIX). Mieszkańcy DPS podejmują działanie polegające na pytaniu o własną tożsamość, a ich opowieści jako „niedokończone projekty” otrzymują szansę scalenia, napisania na nowo, dopóki trwa życie. Cytowany wyżej Maclntyre jest również zwolennikiem twierdzenia, że jednostka jest jedynym autorem swojej biografii. Inaczej twierdzi Paul Ricoeur - możemy być bowiem zaledwie narratorami lub bohaterami narracji, które napisał za nas ktoś inny. Kto napisał biografie mieszkańcom DPS? W dużej mierze ich autorami są „okoliczności działania”, na które nie mieli wpływu. „Okoliczności działania” sprowadziŁy na nich doświadczenie cierpienia, na którym ufundowana jest tożsamość mieszkańca DPS. Jeżeli można tu mówić o tożsamości grupowej, to jej głównym spoiwem jest właśnie cierpienie.

\section{Nieopowiadalne}

„- Nie chce mi się" (Artur).

„- Co ja tera mogę sądzić? Jak ja myślę o dole, a nie o górze? [...] Lubię, lubię te ich zabawy. Tylko nogów nie mam - nie chodzę. [...] Poza tym nie mam pamięci, żeby cokolwiek robić" (Pani X).

„- Człowiek już chodzić nie może.

- Ale kiedyś mógł człowiek chodzić.

- Tak, mógł. Ale teraz już koniec. [...]

- Myślisz, że człowiek to jeszcze pamięta? Nie pamięta! Wzrok straciłam i chodzić nie mogę. Trudno, tak się stało.

- No to jeszcze wszystko przed panią.

- Ja już nikogo nie mam. [...] Lubiłam bardzo kiedyś [mówi teraz podniośle, prawie krzyczy - K.P.]. Lubiłam tańczyć! Zabawę! Tańczyć wesoło! ... I człowiek stracił, stracit młode lata” (Ania i Filomena).

„- A teraz już na niczym nie potrafię. [...] Ja umiem grać na trzech instrumentach, więc jakbym mógt, to też bym pograł sobie. [...] No, ja to marzę, żebym mógł jeszcze, ale ja to nie 
dam rady, grać, chociaż na gitarze. Ale nie dam rady. Prawa ręka mi nie chodzi, więc nawet gryfu nie utrzymam. Już nie mówię o saksofonie, bo płuca wysiadają. A na organach ja też nie dam rady, bo tu trzeba podkręcać i wszystko. I dlatego czuję się taki smutny" (Dominik).

Narracje mieszkańców DPS są heterogeniczne, pozbawione schematów fabularnych i pełne momentów nieprzewidywalnych, które - jak stwierdził Paul Ricoeur - stanowią niezbędną cechę dobrej fabuły. Należą one do osób po przejściach, w przeważającej mierze krytycznie oceniających dotychczasowe życie. Jak pokazują powyższe cytaty z wywiadów, ich wypowiedzi są krótkie, niespójne, urywane, obfitujące w doświadczenie niemożności, niezdolności do działania, utraty dawnego potencjału, choroby uniemożliwiającej aktywność i powrót do życia, braku samodzielności, samotności i zniedołężnienia. Pojawiają się w nich marzenia o dokonaniu czegoś, ale gasi je natychmiastowa rezygnacja. Potencjał do działania tłumią niesprawność, lenistwo lub obojętność.

Przytaczane przez moich rozmówców wydarzenia z ich życia nie są ujęte w reguły kompozycyjne, brak w nich tekstowych mechanizmów spójności oraz wzorca narracyjnego. Pozbawione są logicznego wynikania, epizody nie są poukładane według następstwa czasowego. Posługując się słowami Magdaleny Budziszewskiej, można powiedzieć: „to tak, jakby trauma mocą niesionej przez siebie nieprzewidywalności i przemocy rozrywała tkankę opowieści osoby o jej życiu [...]" (Budziszewska, 2007, s. 25). Niemożność działania wiąże się z niezdolnością opowiedzenia samego siebie. Doświadcza tego również opisywany przez Michela de Certeau umierający: „Opuszczając pole określane przez możliwości czynnego funkcjonowania, wchodzi on w obszar nie-znaczenia. Nic, albo prawie nic, nie da się powiedzieć tam, gdzie nie można już nic robić" (Certeau, 2008, s. 191).

Według Paula Ricoeura tematem wszystkich fabuł może być działanie lub cierpienie. W eseju Cierpienie nie jest bólem, w którym przedstawia sposób rozumienia człowieka „jako bytu zdolnego do wytrzymywania, do znoszenia cierpienia” (Ricoeur, 2002, s. 55), Ricoeur próbuje odnaleźć sens cierpienia poprzez skonfrontowanie go z bólem. Przedstawiając zmiany, jakie wywołuje cierpienie na „osi ja sam-inny” oraz na „osi działania-doznawania” zwraca uwagę, że człowiek w głębokim kryzysie nie potrafi „opowiedzieć siebie". Upośledzone są jego zdolności mówienia, wykonywania czynności, opowiadania i szanowania samego siebie jako osoby działającej moralnie (Ricoeur, 2002, s. 57). Niemożność mówienia zawiera w sobie „pęknięcie między chęcią mówienia i niemożnością mówienia”, które wyrywa się ku innemu w postaci „skargi” (Ricoeur, 2002, s. 58). Człowiek cierpiący niemal zupełnie nie jest zainteresowany swoją przeszłością, nie posiada tożsamości narracyjnej. Wiąże się to z cierpieniem, które:

„polega na ciosach zadanych funkcji opowiadania w procesie ustanawiania osobowej tożsamości. Przypomnijmy: życie to historia tego życia poszukująca sposobu opowiedzenia o niej. Zrozumieć samego siebie to być zdolnym do opowiadania o samym sobie historii zrozumiałych i zarazem możliwych do przyjęcia przez innych, przede wszystkim możliwych do przyjęcia. [...] Cierpienie okazuje się tutaj zerwaniem nici narracyjnej w wyniku skrajnej koncentracji, punktowego skupienia na jednej chwili" (Ricoeur, 2002, s. 58). 
Narracje mieszkańców DPS w Jonkowie są czymś jeszcze mniejszym niż „narracje małe”. To narracje szczątkowe, maksymalnie zredukowane, pełne luk - „narracje litotyczne”. Nieporządek opowiadania jest nie tylko „efektem” (Kaźmierska, 1996, s. 40), lecz regułą konstrukcyjną. Ponieważ ludzi tych charakteryzuje nie-działanie, które pociąga za sobą cierpienie, w narracjach nie ma wymienionych przez Paula Ricoeura prefigurowanych wyobrażeń działania. O ile wyżej próbowałam zrekonstruować oś czasu, która organizuje narracje mieszkańców DPS, o tyle prawdą jest, że w ich narracjach przeważa nieustanne mieszanie się czasów: przeszłość opowiadana jest jak teraźniejszość, a teraźniejszość jak przeszłość; przyszłości nie ma w ogóle. Czas jest tu paradoksalny - i to dużo bardziej paradoksalny niż dla świętego Augustyna, którego przytacza Ricoeur w pierwszym tomie Czasu i opowieści - wymyka się im, rozpada, stanowi problem. Brak przyszłości w narracjach pensjonariuszy zaciera $w$ nich horyzont oczekiwań, a niemożność opowiedzenia przeszłości (luki w pamięci) czynią z teraźniejszości niepewny, niemal nieistniejący grunt.

Moim rozmówcom brakuje woli, by cokolwiek w swoich narracjach uporządkować. Przeszkody stwarza im też instytucja, w której tkwią, bowiem „niemożność wyrażania jest więc o wiele starsza niż niknące wraz z umieraniem wysiłki mówiącego. Jest wpisana we wszystkie procedury izolowania śmierci lub wypychania jej poza granice miasta, poza czas, pracę i język, aby ochronić jakieś miejsce" (Certeau, 2008, s. 195). Jak wykażą dalsze analizy, mieszkańcy DPS nie są świadomi, w jakich historiach uczestniczą, co również świadczy o zaburzeniu ich narracyjnej tożsamości. Ich negatywny stosunek do innych (bliskich, innych mieszkańców DPS, personelu) ma związek z cierpieniem łączącym się z niezdolnością do opowiadania - historie ludzkie są bowiem wplecione w historie innych. Niemożność opowiedzenia siebie wyklucza ich z grona tych, którzy to potrafią, upośledza w stosunku do innych i stawia poza wspólnotą.

Czy mimo tak skrajnie posuniętej niespójności, braku schematów fabularnych, zwartych elementów kompozycyjnych i zaburzenia na osi czasu wykluć się może z tych narracji jakiś sens, jakaś całość? Tak, jeśli wyjdzie im naprzeciw intryga, reguła kompozycyjna lub inna, silniejsza narracja. 


\section{MIMESIS II, CZYLI O OCALAJĄCEJ FUNKCJI NARRACJI}

Analiza „litotycznych opowieści” mieszkańców DPS była nieubraną w opowieść prezentacją tego, kim są i co ich konstytuuje, zestawieniem tego, co pensjonariusze chcieli o sobie opowiedzieć. Teraz zajmę się „wejściem do królestwa fikcji” - mimesis /I (Ricoeur, 2008a, s. 85), która intensyfikuje wszystkie aspekty przedrozumienia działania, „nową konfigurację, powstającą dzięki fikcji przedrozumianego porządku akcji” (Ricoeur, 2008a, s. 85) - „wielkimi narracjami” Stanisława Wyspiańskiego, Witolda Gombrowicza i Williama Szekspira, kompilowanymi w autorskie scenariusze Wacława Sobaszka, które porządkują doświadczenie mieszkańców DPS i ubierają je w opowieść. Jeśli potraktować to, co usłyszałam od mieszkańców DPS, jako „bezładne, nieuformowane i aż do przesady nieme czasowe doświadczenie", intryga byłaby tym, co pomaga je zrefigurować - nadać im sens i porządek.

\section{Historia pracy Teatru Węgajty w DPS w Jonkowie}

Obecność Teatru Węgajty/Projektu Terenowego w DPS w Jonkowie datuje się mniej więcej od początku lat dziewięćdziesiątych, czyli niemal również od powstania DPS. Niektórzy mieszkańcy precyzyjnie pamiętają, kiedy teatr pojawił się w DPS - jeden z nich podczas spotkania Domena publiczna "Wesela” dokładnie obliczył, że miało to miejsce osiemnaście lat wcześniej. Początki pamięta także Erdmute Sobaszek: „To było tak, że pewnego dnia u nas zjawiły się dwie panie. Jedna z nich to była pracownica socjalna DPS. Druga - nie pamiętam. Niewykluczone, że ówczesna dyrektorka. Pytały się, czy nie moglibyśmy u nich coś zrobić. No i ochoczo się zgodziliśmy [...]”3. Zaczęło się od koncertu litewskiego zespołu Intakas, który zarazem pokazał Sobaszkom pierwsze, potem przez wiele lat powtarzane, układy taneczne. Było to więc dla Teatru, jego praktyki artystycznej, wydarzenie na swój sposób przełomowe. Koncert przerodził się w zabawę taneczną; jak mówi Erdmute Sobaszek: „Tam wtedy było duuużo więcej ludzi na tyle sprawnych, żeby tańczyć!"4. Ów epizod zaowocował regularnie urządzanymi w DPS potańcówkami, imprezami muzyczno-tanecznymi, warsztatami plastycznymi, teatralnymi i zapustami, mającymi na celu aktywny udział mieszkańców. Odbywały się również wydarzenia dla szerszej publiczności, na przykład słynne Międzynarodowe Seminaria Teatralne, w których brali udział specjaliści zajmujący się teatrem i muzyką nie tylko z Polski, ale z całej Europy.

Sobaszkowie z sentymentem opowiadają o tych początkach. Ówczesna dyrekcja była bardziej otwarta na ich działania, o czym świadczy fakt, że Teatr Węgajty pracował z pensjonariuszami przedpołudniami, a nie - jak teraz - po godzinach, w ukryciu, "gdy nie działa biuro" (Sobaszek, 2009). Więcej było sprawnych ludzi, więc łatwiej było coś zrobić. Także relacje między mieszkańcami były inne: „po prostu ludzie tańczyli ze sobą i ten kontakt byt” (Erdmute Sobaszek). „To było wtedy najlepsze miejsce, najbardziej otwarte

3 Z e-maili wymienionych między Erdmute Sobaszek a K.P. między 8 marca a 12 kwietnia 2012 roku.

4 Tamże.

SLH 2/2013 | str. 159 
dla nas" - mówił Wacław Sobaszek po premierze spektaklu Wesele - domena publiczna zespołu Hazbeszkwej w lipcu 2009 roku.

Na pewnym etapie „spotkanie potańcówkowe” przestało Sobaszkom wystarczać; jak powiedziała Erdmute Sobaszek: „Znaliśmy się z widzenia. Wiedzieliśmy, że pan Janek poradzi sobie na tamburynie. Wiedzieliśmy, że ktoś inny będzie tańczył. Byliśmy w tym miejscu pozytywnie nastawieni, ale nie znaliśmy nawet ludzi z nazwiska. Odwiedzamy się, znamy się z widzenia, ale tak naprawdę się nie znamy. To mi ciążyło, czułam, że to nie w porządku, że się spotykamy, ale się nie spotykamy". Wtedy pojawił się pomyst warsztatów plastycznych, ukierunkowanych na proste formy, takie jak klejenie lampionów, pieczenie pierników lub tworzenie prostych masek zapustnych. Te ostatnie chyba najbardziej przypadły do gustu mieszkańcom. Idea zespołowej pracy i wspólnego tworzenia przekuła się na praktykę i stała się początkiem budowania bardziej pogłębionych relacji z mieszkańcami. Podczas wspólnej twórczej pracy można było czuć się swobodnie, opowiadać niecenzuralne dowcipy, było miejsce na rozmowę, która pozwalała bliżej się poznać. Sobaszkowie odkryli, że każdy z mieszkańców „ma swoją drogę, swoje imię i nazwisko, swoją historię" (Erdmute Sobaszek). Mieszkańcy zaczęli Sobaszków interesować, a wręcz na swój sposób fascynować. Jak mówi Erdmute Sobaszek „zaczęliśmy zauważać, że ktoś tam jest i że to nie jest tylko publiczność".

\section{Wejście do przestrzeni prywatnej - warsztat Przetwarzanie pamięci}

Z czasem - paradoksalnie - praca w DPS stawała się coraz trudniejsza. Jedną z przyczyn tego stanu rzeczy była zmiana personelu. DPS stawał się coraz bardziej „toksyczny”. Spotkania z mieszkańcami trzeba było organizować popołudniami, kiedy mieszkańcy już przysypiali i byli właściwie nieaktywni. Interakcję uniemożliwiały także starość i pogłębiające się choroby pensjonariuszy. Doświadczenie to opisuje Erdmute Sobaszek: ,jak się tam wchodziło, to się widziało rząd ludzi kompletnie niekontaktujących", coraz więcej było osób na wózkach i nie wiadomo było, co z nimi robić: „Zastanawialiśmy się, jak tu podejść do takiego wózka. I ci ludzie też mają świadomość, że nikt do nich nie podchodzi. Także z ich strony pod tym względem pojawiła się bezradność". Forma nawiązywania relacji, jaką było spotkanie potańcówkowe, wyczerpała się, bo tańczyły tylko cztery osoby. Atmosferę w DPS kształtowały bliskość śmierci i odchodzenia. Pojawiła się potrzeba utrwalenia spotkań między Teatrem a mieszkańcami - rozmów, efemerycznych zdarzeń, historii osobistych: „tego, co mieszkańcy DPS mówią o sobie, co chcą przekazać, utrwalić" (Sobaszek, 2009). Pomysł na to przyszedł w czerwcu 2008 roku, gdy grupa studentów IV roku Wydziału Stosowanych Nauk Społecznych Uniwersytetu Warszawskiego pod kierunkiem profesor Aldony Jawłowskiej pojawiła się w Węgajtach w ramach praktyk terenowych. Tak opisuje ten przełomowy moment Mute Sobaszek: „Ja miałam taki okres, że myślałam, że to jest zupełnie bez sensu, że nie ma z nimi kontaktu. I właśnie szukaliśmy z Wackiem, żeby coś takiego wymyślić (wiele razy o tym rozmawialiśmy), żeby 
ten kontakt znaleźć, i wtedy wy się pojawiliście”. Wacław Sobaszek wyszedł z propozycją warsztatu Przetwarzanie pamięci. Jego celem było pokazanie, że mieszkaniec DPS to nie tylko wykluczony, ale homo narrans, istota narracyjna.

$\mathrm{Na}$ warsztat składały się: rozgrzewka teatralna (adaptacja przestrzeni poprzez ciato i wzajemny kontakt), ćwiczenia głosowe, budowanie zespołowości poprzez kontakt fizyczny, nauka tradycyjnych tańców i gry na tradycyjnych instrumentach, organizacja potańcówki w DPS, podczas której przeprowadzano wywiady z mieszkańcami, dyskusja i odsłuchiwanie zarejestrowanych rozmów, w końcu praca nad etiudami teatralnymi, których podstawą był zebrany materiał etnograficzny. Wywiady dotyczyły między innymi dawnych (czyli sięgających lat młodości rozmówców) zwyczajów związanych z potańcówką. Wacław Sobaszek przygotował kwestionariusz swobodnego wywiadu pogłębionego, składający się z trzech ogólnych zagadnień: 1. historie samoopowiadające się; 2. pamięć o babciach, dziadkach; 3. obraz potańcówki w młodości. Zagadnienia te były podstawą „improwizowania” pytań szczegółowych, zadawanych mieszkańcom podczas toczącej się wokół potańcówki.

Po zakończeniu działania w DPS studenci rozeszli się po okolicznych łąkach i lasach, gdzie odsłuchiwali wywiady i spisywali zasłyszane historie. Potem był warsztat teatralny: ćwiczenia fizyczne, głosowe, wspólny bieg po lesie, rozmowa o zebranym materiale oraz przygotowanie etiud, inspirowanych wywiadami z mieszkańcami. Wypowiedzi mieszkańców wzbogaciły wiedzę na temat dawnej potańcówki; niektóre miały niezwykły potencjał dramaturgiczny, a nawet poetycki. W końcu studenci zaczęli mówić historiami o dziadkach i babciach - najpierw mieszkańców, potem swoich własnych. Były to luźne skojarzenia, nieświadome obrazy, które narzucała pamięć. Narzędziem ewokowania wspomnień był przekazywany w kole kapelusz: ktoś zaczynał, potem zdejmował z głowy kapelusz, przekazując go kolejnej osobie, która zaczynała opowiadać własną historię. Następnego dnia studenci pracowali z tak „napisanym” tekstem, uruchamiając ciało i próbując odnaleźć własną część przestrzeni, kojarzącą się automatycznie i nieświadomie z wypowiadanym tekstem. Słowa próbowały znaleźć swój wymiar fizyczny. Wartość tej pracy po upływie czasu doceniła Erdmute Sobaszek: „Zamiast konfrontacji w grupach: czyli grupa artystyczna i grupa mieszkańców stworzony został kontakt indywidualny. To, że oni wtedy kompletnie zmienili swoje zachowanie, to nam wskazało drogę metody pracy aktorskiej: w cztery oczy, bezpośrednie spotkanie".

\section{Cel warsztatu Przetwarzanie pamięci}

Warsztat Przetwarzanie pamięci był pierwszą próbą, pierwszym etapem nadawania „przedrozumieniu działania” mieszkańców DPS wymiaru narracyjnego. Dokonało się to poprzez zainscenizowanie doświadczenia z przeszłości. Wtedy nas - uczestników warsztatu - dopadły najsilniej Augustyńskie paradoksy czasu (Augustyn, 2007). Przeszłe doświadczenia mieszkańców zaczęły ożywać na naszych oczach, stawać się ponownie 
w teraźniejszości. Pojawiła się potrzeba ujęcia ich w ramy fabularne - poprzez ponowne opowiedzenie ich historii i wspomnień naszymi ustami, a w dalszym etapie językiem ciała i teatru. Na bazie „litotycznych opowieści” mieszkańców DPS w toku tworzenia etiud teatralnych powstały inspirowane nimi opowieści fikcyjne - opowiedziane historie ewokowały bowiem w wyobraźni coraz bardziej konkretne obrazy, a ich kształt prowokowały pytania, dzięki którym dopisywano kolejne, fikcyjne opowieści. Poprzez ponowne opowiedzenie prawdziwych historii mieszkańców DPS studenci podjęli próbę nadania ich życiu, opowieści, a nade wszystko czasowi, utraconej spójności.

Jak Sobaszkowie stwierdzili po upływie roku (Sobaszek, 2009) ${ }^{5}$, warsztat Przetwarzanie pamięci ukazał im sens i potrzebę dotarcia do przestrzeni prywatnej mieszkańców DPS jako sposobu nawiązania bezpośrednich relacji, nieregulowanych przez DPS, wymykających się spod kontroli tej instytucji. Dokonało się to poprzez zainscenizowanie teatralnego „spotkania”. Działanie studentów WSNS zachęciło Teatr Węgajty do głębszego poznania „bliskich nieznajomych” oraz przyjrzenia się ich „litotycznym opowieściom”. Wcześniej taki kontakt udawało się nawiązać incydentalnie. Postępującą barierą był bowiem wzrost liczby osób niekontaktujących oraz zasieki stworzone przez instytucję - DPS. Kontakt bezpośredni pozwalał tę barierę obalić. Erdmute Sobaszek podkreśla w tym aspekcie wartość narracji: „Sama ta sytuacja, że podchodzi student ze swoim sprzętem do nagrywania i mówi: «proszę mi opowiedzieć». [...] Z jakąś ulgą zaczęli opowiadać, wiedząc, że ktoś chce ich wysłuchać".

Sobaszkowie, wprowadzając studentów do DPS z dyktafonami, mieli również nadzieję na zebranie materiału etnograficznego, który mógłby stać się bazą do ich dalszej, własnej, wewnętrznej pracy teatralnej, a zatem uczynienia z mieszkańców DPS poniekąd materii do „obróbki artystycznej”. Pomysł spektaklu na podstawie opowieści mieszkańców pojawił się podczas warsztatu, po przedstawieniu przez studentów WSNS zebranego materiału. Pośrednim założeniem badań przeprowadzonych wśród mieszkańców było - jak wynika z rozmaitych wypowiedzi Sobaszków - znalezienie artystycznej użyteczności czy też przydatności tych ludzi, odnalezienie dawno zapomnianych i nierozwijanych talentów, przekształcenia ich w jednostki „działające”, a nie tylko „doznające”. Miało się to dokonać poprzez wpisanie ich doświadczenia w opowieść.

5 Sobaszkowie opowiedzieli o tym także podczas dyskusji odbywającej się po pokazie Wesela, podczas Wioski Teatralnej 2009. 


\section{Litotyczne narracje wpisane w wielkie opowieści: Wyspiański, Gombrowicz i Szekspir w DPS}

"Opowiadamy historie, gdyż ostatecznie ludzkie żywoty muszą być opowiedziane
i zasługują na to. Powyższa uwaga nabiera mocy,
gdy wspominamy o konieczności ocalenia historii zwyciężonych i pokonanych.
Cała historia cierpienia woła o pomstę i domaga się opowieści".
P. Ricoeur, Intryga i historyczna opowieść (Ricoeur, 2008a, s. 111)

Według Paula Ricoeura funkcję zapośredniczającą w narracji pełni intryga na trzech poziomach (Ricoeur, 2008a, ss. 99-100). Jednym z nich jest pośredniczenie między jednostkowymi zdarzeniami a sensowną historią pojmowaną jako całość. To, co tworzy konfigurację z prostego następstwa zdarzeń, to właśnie intryga nazywana przez Paula Ricoeura „syntezą niejednorodnego”. Porządkuje ona czasowe doświadczenie, nadając mu jedność, obala Augustyńskie paradoksy czasu, czyniąc je „produktywnymi”. Intryga, którą zawiera „wielka narracja”, umożliwia „oparcie w czymś większym i mocniejszym niż własne ja - w innych, we wspólnocie" (Straś-Romanowska, 2010, s. 30), ukierunkowuje proces samorozumienia, zwłaszcza w sytuacjach krytycznych i granicznych. W ten sposób przewartościowaniu ulega ponowoczesny indywidualizm - wspólnota okazuje się jednostce potrzebna i trzeba ją chronić, by mogła za nią opowiadać.

Dzięki licznym spotkaniom, rozmowom, warsztatom podczas kolejnych odwiedzin w DPS członkowie i adepci Teatru Węgajty zyskali kompetencję „praktycznego rozumienia” (Ricoeur, 2008a, s. 82) doświadczenia mieszkańców DPS. Tak narodziła się potrzeba dalszej pracy, stworzenia czegoś namacalnego, scalonego i konkretnego, przekucia owego „praktycznego rozumienia” w „rozumienie narracyjne”, nadania doświadczeniu mieszkańców DPS cech dyskursywnych i „porządku syntagmatycznego” (Ricoeur, 2008a, s. 82). „Litotyczne narracje” mieszkańców DPS okazały się warte ocalenia - zainspirowały estetykę przedstawień i formułę pracy teatru. Oznaczało to konieczność zapośredniczenia ich przez wzorce kulturowe, wpisania „litotycznych narracji” mieszkańców DPS W „wielką narrację” lub - jak powiedział Wacław Sobaszek - „wspólnotę rymowanek” (Sobaszek, 2009).

Trzeba było jeszcze „sformalizować” wspólnotę. Tak powstał zespół Hazbeszkwej, którego nazwę stworzyły pierwsze litery imion jego członków, czyli Haliny, Albina, Zofii, Barbary, Emilii, Sebastiana, Zygmunta, Krystyny, Wacława, Erdmute i Jana. Jego pracę obserwowałam w latach 2009-2012 i chciałabym opisać jej rezultaty w postaci trzech spektakli w reżyserii Wacława Sobaszka: Wesela - domeny publicznej, Iwony poślubionej oraz Snu nocy letniej.

Struktura zespołu Hazbeszkwej jest specyficzna - po części składa się on z mieszkańców DPS, a po części z członków Teatru Węgajty i adeptów Innej Szkoły Teatralnej. Nie 
jest również stała - zachodzi w niej ciągła rotacja głównie spowodowana problemami zdrowotnymi wykonawców. Mieszkańców DPS dzieli się na „performerów” i „adeptów”. Performer to "hazbeszkwej” bardziej doświadczony, adept to ten, który stawia pierwsze kroki. Warto podkreślić fakt, że Wacław Sobaszek, „dyrektor artystyczny” Hazbeszkwej, unika określenia aktor, chcąc odsunąć skojarzenia z profesjonalnym aktorstwem teatru mieszczańskiego. Słowo „performer” z jednej strony nawiązuje do słynnego eseju Jerzego Grotowskiego (Grotowski, 1990), jak również do performatyki Richarda Schechnera (Schechner, 2006). Grotowski nazwał performera „człowiekiem czynu. A nie człowiekiem, który gra innego" (Grotowski, 1990, s. 214). Teorie performatyki rozpinają różne odmiany aktorstwa między dwoma skrajnymi krańcami: „aktorstwem minimalnym lub nawet nieaktorstwem" a "całkowitym aktorstwem szamanów i opętanych w transie" (Schechner, 2006, s. 201). DPS-owy performer paradoksalnie łączy te dwie skrajności. Jeden z nich grywał Heroda w widowiskach obrzędowych, inny bywał performerem w życiu codziennym, robiąc dowcipne wykłady z języka migowego. Jego działania sceniczne wraz z szeregiem czynności wykonywanych na scenie będących czymś innym niż granie postaci - są „performansami bez wzorca”, a ponieważ publiczność może odebrać je jako przynależne postaci - mimo że performer przez cały czas działa prywatnie - podpadają również pod kategorię „performansów wzorca domniemanego” (M. Kirby, cyt. za: Schechner, 2006, s. 202).

Na początku działalności Hazbeszkwej pojawił się problem z regułą kompozycyjną, czyli doborem trafnej opowieści fikcyjnej: „Było wiele różnych pomysłów, nie ma sensu o nich opowiadać, ponieważ z nich wszystkich zrezygnowaliśmy. Bo zdaliśmy sobie sprawę, że ten pomysł jest zbyt odstający od rzeczywistości. I że trzeba to robić w domu pomocy społecznej, żeby było to bliższe jego mieszkańcom. Żeby to nie polegało na tym, że robi się malowniczy happening, do którego może udałoby się porwać kilka osób" (Wacław Sobaszek). Teatr w DPS miał być bliski jego mieszkańcom, tworzony z myślą o nich - ambicje i efekty artystyczne były sprawą drugorzędną. Tym bardziej, że ze śpiewanymi przez panią Krystynę pieśniami Studzienka czy Poręba DPS okazał się prawdziwą skarbnicą „tradycyjnego” repertuaru. Przywołana przez panią Antoninę stara pieśń kurpiowska Ballada o starym Jakubku, której bohater miał trzy córki i wędrował po świecie, tułając się od jednej do drugiej, podsuwała pomysły z Królem Lirem Williama Szekspira: „Może od niej zacząć? Co robić, wprowadzić do DPS Szekspira? No nie! I wtedy ktoś podsunąt pomysł z Wyspiańskim" (Sobaszek, 2009).

Podczas pracy nad Weselem mieszkańcy DPS mówili, że dobrze czują się w swoich rolach, że są jakby „specjalnie dla nich napisane”. Role dobrano do warunków fizycznych i osobistych doświadczeń biograficznych. Próby, które rozpoczęły się kilka miesięcy przed pokazem ${ }^{6}$, dostosowano do codziennego porządku i rytmu dnia DPS - w pierwszej kolejności przygotowywano sceny z osobami, które nie miały akurat rehabilitacji,

6 Najtrudniejsza z dotychczasowych była praca nad Iwona poślubiona; trwała bowiem prawie dwa lata. 
nie jadły posiłku, nie odwiedzali ich bliscy. Z uwagi na wzajemną wrogość mieszkańców początkowo pracowano indywidualnie, w pokojach, w parach. Panował lęk przed próbami zbiorowymi.

W pracy nad Weselem bardzo istotny był warsztat plastyczny, powiązany z warsztatem przygotowywania masek zapustnych. Tym razem mieszkańcy dostali zadanie wykonania lalek o naturalnych rozmiarach dziecka przy zastosowaniu bardzo prostej techniki. Praca ta wyzwoliła w grupie warsztatowej duże emocje. Mieszkańcy zżyli się z przygotowywanymi przez siebie lalkami. Katarzyna chciała wziąć swoją lalkę do pokoju: „Było oczywiste, że [Katarzyna] jest osobą, która tej lalki najbardziej potrzebuje” (Erdmute Sobaszek). Inna lalka grała w Weselu i była animowana przez Halinę, która również ogromnie się z nią zżyła - potem trzymała ją nawet przy swoim łóżku i nie bardzo chciała przyjąć do wiadomości, że zrobiła ją pani Henia, której nie cierpi; Albin pytał, czy jest do tej lalki podobny. Lalka grająca w spektaklu Isię otrzymała nawet własne imię.

Wesele - domena publiczna według autorskiego scenariusza i w reżyserii Wacława Sobaszka otworzyło festiwal Wioska Teatralna w 2009 roku. Domena publiczna - a zatem Wyspiański z Internetu, „wielka narracja” nieograniczenie dostępna w zbiorowej i indywidualnej pamięci, której „dialogi można było zacząć właściwie z pamięci, a więc niedokładnie, zmieniając" (Sobaszek, 2009). Coś, co jest szeroko dostępne, przechowywane w pamięci, znane, co daje się bez większego uszczerbku prześwietlić przez „narrację litotyczną”, bo przecież „my wszyscy razem mamy w pamięci tamto wesele oraz inne wesela, różne, wymieszane” (Sobaszek, 2009). W działaniach teatralnych „wielka narracja” pełniła rolę drugorzędną, „podpierającą pamięć”, pozwalała na niedokładność i brak precyzji. Twórcy spektaklu mieli nadzieję, że „może się czwarty wieszcz w grobie nie przewróci, jeśli nawet poprzerabiamy jego tekst, perłę dziedzictwa” (Sobaszek, 2009).

Celem spektaklu było otwarcie i przełamanie inercji: „Chodziło o to, żeby to miejsce ożywić w takim podstawowym sensie. [...] Żeby zaproponować tym ludziom jakiś rodzaj przebudzenia mimo instytucjonalnej opresji, w jakiej się znajdują" (Wacław Sobaszek). Być może dlatego Wacław Sobaszek wybrał właśnie tę „wielką narrację” - wszak utwór Stanisława Wyspiańskiego również jest opowieścią o przełamywaniu inercji, wyrwaniu się z chocholego tańca. Pośrednio była to opowieść o ludziach z DPS oparta na zdobytej przez Sobaszków wiedzy na temat ich biografii.

Pracując z mieszkańcami DPS w Jonkowie, Teatr Węgajty, mimo koncentracji na idei „teatru potrzebnego”, wciąż poszukiwał w kulturze DPS szeroko rozumianej tradycji. Tego, co dawne i co przechowuje pamięć, i jednocześnie tak trwałe, że może to przechować nawet pamięć ułomna. Sam Wacław Sobaszek mówit, że w DPS „wieś znalazła schronienie", że można odtańczyć tu znane tańce, posłuchać tradycyjnych pieśni wchodzących w repertuar Teatru (Sobaszek, 2009). W Albinie Sobaszkowie odkryli ludowego rzeźbiarza - jego rzeźby przypominają warmińskie „świątki”. Śpiewaną przez panią Antoninę pieśń kurpiowską o trzech córkach i ojcu, Balladę o starym Jakubku, wprowadzono jako prolog 
Wesela - domeny publicznej. Także wywiady przeprowadzone podczas warsztatu Przetwarzanie pamięci przyniosły obraz wsi z czasów młodości mieszkańców, a zatem sprzed kilkudziesięciu lat. Potrzeba dialogu z kulturą tradycyjną niewątpliwie wiązała się z wyborem Wesela jako tekstu wyjściowego do pracy z mieszkańcami DPS.

Zdaniem reżysera Wesela w DPS jak w soczewce widać rozmaite zachowania społeczne, a więc poniekąd DPS jest obrazem społeczeństwa - tak jak bronowicka chata w dramacie Wyspiańskiego: „Czy to nie jakaś szersza sprawa, coś co mnie może dotyczyć, fenomen do zbadania? Czy to nie cała zbiorowość, nie my się w tym odbijamy? Te zachowania, napięcia, uwikłanie w instytucję, w DPS, to zwierciadło nas samych? Społeczność jako zbieranina, wspótistnienie ludzi na siebie skazanych. Czy można odnaleźć coś co ich łączy?" (Sobaszek, 2009). Podobne sensy w Weselu dostrzega pensjonariuszka DPS, Barbara: „Chodzi tu zapewne o niezgodę w społeczeństwie, że każdy na swój sposób spędza czas, każdy co innego robi. I dlatego panuje ogólna niezgoda, zamiast tej właściwej zgody". A zatem Wesele stało się poniekąd spektaklem o budowaniu wspólnoty.

W kolejnych scenach dramatu postaci pojawiają się najczęściej w dialogujących ze sobą parach - postać z ludu wchodzi w interakcję z reprezentantem tak zwanej młodopolskiej inteligencji. Ten zabieg konstrukcyjny Wyspiańskiego stał się kluczowy w paraspektaklu zespołu Hazbeszkwej. W dwójkowych scenach pensjonariusz DPS wchodził w interakcję z aktorem Teatru Węgajty. Przy tym mieszkaniec DPS grał rolę inteligenta, a aktor z Teatru Węgajty - człowieka z ludu. Model dwójkowych scen zainspirowany Weselem będzie się powtarzał w innych spektaklach Hazbeszkwej. Geneza tej reguły kompozycyjnej wywodzi się także z DPS-owskich potańcówek, podczas których zawsze aktor Teatru Węgajty zapraszał do tańca pensjonariusza DPS.

W rozmowie publicznej Domena publiczna „Wesela”, która odbyła się bezpośrednio po premierze spektaklu, wzięli udział członkowie i adepci Teatru Węgajty, publiczność Wioski Teatralnej, wszyscy mieszkańcy grający w spektaklu oraz personel DPS. Podczas spotkania pokazano film, kręcony na przestrzeni kilku miesięcy, ukazujący rozmaite wizyty Sobaszków w DPS. Montaż filmu i wybór zaprezentowanych scen miał na celu ukazanie dobrych stron mieszkańców, ich ukrytych talentów i potencjału: na przykład tego, że pan Janek doskonale posługuje się językiem migowym, a Albin rzeźbi wspaniałe drewniane figurki. Miał dowieść, że ci ludzie nie są „zbędni”, ale społecznie użyteczni, że praca z nimi ma sens i może być atrakcyjna dla innych. W filmie wystąpiła między innymi schorowana pani Leokadia, która przykuta do łóżka śpiewała zabawną pieśń o Pupkach, jej rodzinnej wsi, trafnie komentującą marazm panujący w DPS. Obraz ten wywołał rodzaj szoku.

Zastanawiałam się, czy pani Leokadia wiedziała o tym, że kamera jest włączona i że ją pokaże? Czy ukazanie jej w sytuacji intymnej, leżącej w tóżku we własnym pokoju, z widocznymi śladami choroby i niemocy, nie naruszyło jej godności? Z drugiej strony dlaczego nie pokazywać osób chorych i udawać, że nie istnieją? Bo naruszają zasady estetyczne, wymogi kultury wizualnej? Ten antyestetyczny obraz - leżącej w łóżku schorowanej 
kobiety naruszył jej intymność, ale zarazem przywrócił ją światu. Kilka osób spośród festiwalowej publiczności zareagowało niesmakiem, film wzbudził kontrowersje. Naruszono ogromne tabu. Przypomina to kontrowersje, jakie w szerokiej debacie publicznej wzbudzały filmy Artura Żmijewskiego, w których manipuluje swoimi modelami: zmusza starszego człowieka do odtworzenia obozowego tatuażu (80064), głuchym każe śpiewać Jana Sebastiana Bacha (Lekcja śpiewu 1 i Lekcja śpiewu 2), a grupie przypadkowych ludzi powtarzać traumatyczny eksperyment stanfordzki (Powtórzenie). Obraz śpiewającej pani Leokadii najbardziej jednak kojarzy się z filmami, do których Żmijewski „używat” niepełnosprawnych - Karolina i Na spacer. Bohaterką Karoliny jest młoda kobieta chora na zaawansowaną osteoporozę, która - przykuta do łóżka - przez osiem minut trwania filmu opowiada o swoim bólu. Na spacer ukazuje zaś pacjentów z ośrodka rehabilitacyjnego dla osób sparaliżowanych, animowanych przez swoich opiekunów, „wyprowadzających ich na spacer". Stosowany przez Żmijewskiego sadyzm ma głęboko humanistyczny wymiar właśnie poprzez przywrócenie widzialności temu, co antyestetyczne. A jakie ma znaczenie dla modeli, komentuje sam artysta, tłumacząc udział jednego z nich w filmie Na spacer: „Zazwyczaj leży całymi dniami w swoim pokoju w domu opieki społecznej, nieobecny, nieistniejący, tak, jakby był już martwy. Chętnie oddałby część swojej godności, by nie być sam" (Żmijewski, 2009, s. 139). To samo można powiedzieć o performerach Hazbeszkwej.

Wesele było pierwszą „wielką narracją” opowiedzianą ustami i ciałami autorów „opowieści litotycznych”. Dzięki przekazowi teatralnemu zostali ponownie wpisani we wspólnotę komunikacyjną.

Kolejnym spektaklem przygotowanym przez zespół Hazbeszkwej w 2010 roku była Iwona poślubiona na podstawie kilku tekstów Witolda Gombrowicza: Iwony, księżniczki Burgunda, Ślubu, Ferdydurke i opowiadania Szczur (scenariusz i reżyseria Wacław Sobaszek). Było to drugie podejście do Gombrowicza w historii Teatru Węgajty po przełomowej Synczyźnie. Jak wspomniałam, była to również najtrudniejsza (proces przygotowania trwał prawie dwa lata), a zarazem najdojrzalsza praca zespołu Hazbeszkwej. O ile Wesele było przede wszystkim spektaklem o inercji, a także - na poziomie metaopowieści, ze względu na wątki interakcji między kulturą wysoką a ludową - o pracy Teatru Węgajty z mieszkańcami DPS, o tyle Iwona skupiła się na mechanizmach i relacjach w łonie instytucji totalnej. Dwór księżniczki Burgunda stał się metaforą pełnych hipokryzji relacji panujących w strukturach DPS. Tak jak u Gombrowicza rodzina królewska przyjmuje Iwonę jako kandydatkę do ręki Filipa, a zarazem podstępnie dąży do jej unicestwienia podobnie DPS przyjmuje nieradzących sobie w życiu pod swój dach z misją niesienia im pomocy, ale jednocześnie doprowadza do ich wykluczenia i izolacji od społeczeństwa. Kluczową rolę grała tu tytułowa Iwona „cimcirymci” - to, co wymyka się określeniu, modelowaniu, naznaczaniu, co budzi pogardę i nie jest do niczego potrzebne, ale nad czym trudno zapanować. Na Iwonę więc można było patrzeć jako na metonimię mieszkańca DPS; podobnie jak na występującego w spektaklu Pijaka (będącego syntezą Pijaka ze Ślubu i Żebraka z Iwony, księżniczki Burgunda) - kogoś równie nieobliczalnego, kto poprzez 
pokazywanie „palicem” wskazuje na toksyczne oddziaływanie formy: w tym wypadku struktury funkcjonowania domu pomocy społecznej. Pijak budzi też proste skojarzenia z alkoholikami, prawdziwym utrapieniem personelu DPS, a zarazem - jak powiedziała Mute Sobaszek - „zaprzeczeniem panującego tam porządku”. Co ciekawe, w postaci z dworu: Królową, Króla, Damę Dworu wcielili się mieszkańcy DPS.

„Litotyczne opowieści” mieszkańców stały się źródłem inspiracji dla treści i formy scenariusza Iwony poślubionej. Posługując się językiem Paula Ricoeura, można stwierdzić, że intryga, jaka wykluła się z fabuł dzieł Gombrowicza, ustaliła „sekwencyjne powiązanie” (Ricoeur, 2008a, s. 86) między tymi opowieściami, między ich sprawcami, działaniem i doznawaniem. Na pomysł dołączenia Szczura wpadł Wacław Sobaszek, gdy Albin, mający za sobą epizod w więzieniu, opowiedział mu historię o więziennych szczurach obgryzających ciała zmarłych więźniów oraz o torturach polegających na przywiązywaniu więźnia do kraty i pozwalaniu, by szczury chodziły po nim przez całą noc. Opowieść Albina zainspirowała scenę z Pijakiem siedzącym za „kratą” tekturowego „więzienia”. Samo opowiadanie Gombrowicza „posłużyło zaś do tego, by działaniu Iwony nadać cechy feministycznego buntu, uzbroić ją w siłę przeciwstawiania się męskiemu spojrzeniu i założonemu scenariuszowi, który miał ją doprowadzić do samobójstwa. Obronić ją"7.

W pracy nad postacią Iwony inspirację stanowiła opowieść innej mieszkanki DPS, pani Lucjanny. Opowiedziała ona kiedyś Sobaszkom historię serii samobójstw, do których dochodziło w jej rodzinnej wsi Gołogórze. Iwona w spektaklu Hazbeszkwej popełnia samobójstwo w wyniku nacisków, oczekiwań i manipulacji, jakie wywiera na nią dwór. Pani Lucjanna w swojej opowieści również podkreśla, że samobójstwa w rodzinie z jej wsi wywołane były wtrącaniem się „starych” w sprawy „młodych”. W spektakl wpleciono pieśni z repertuaru Krystyny. Postacie z dzieł Gombrowicza weszły w pole gry, którym był dziedziniec DPS, w procesji kierowanej przez Albina i jego drewnianą rzeźbę Światowida. Pojawił się również motyw „teatru w teatrze” - teatrzyk kukiełkowy stworzony z figurek Albina.

Podczas pracy nad Iwona ostateczny tekst spektaklu powstat w wyniku pracy kolektywu, prowadzonego przez Wacława Sobaszka. Jednak to budowanie wzajemnych relacji wciąż było trudne. Mówi o tym Mute Sobaszek: „Ta granica, ten dziwny świat, bańka, która odgradza tych ludzi - ona tak samo tworzy zachowania we mnie. Mimo że ja tych ludzi od lat znałam, nie jestem na to odporna”. Nie ulega wątpliwości, że teatr jest tym, co mieszkańców integruje, chociaż wciąż odizolowany pozostaje „drugi plan”. Spektakle Hazbeszkwej są rytuałami w rozumieniu Turnerowskim (Turner, 2005), bo za każdym razem gromadzą pewną grupę w gruncie rzeczy przypadkowych jednostek, które stają się zbiorowością, dokonują wzajemnej inkluzji.

Ostatnią pracą, którą przygotował Teatr Węgajty/ Projekt Terenowy z mieszkańcami DPS w Jonkowie, był Sen nocy letniej Williama Szekspira (scenariusz i reżyseria Wacław

7 Por. strona internetowa Teatru Węgajty (http://free.art.pl/teajty/pliki/tresc.php?go=33; dostęp: 2 grudnia 2012 roku). 
Sobaszek). A więc jednak Szekspir, przed którym na początku był jakiś niezrozumiały lęk i ironia: „Pamiętam, to było zimą. Jechaliśmy z panem Wackiem do nich do teatru na taką sobie tam lekką próbę, pośpiewanie, potańczenie. Pytamy, czy coś jeszcze będziemy grać. A pan Wacek myśli, myśli i to bardzo myśli, i mówi: to będzie Szekspir. A my pytamy: A co z Szekspira? Pewnie Lord leje łzy. Tak że było to powiedziane żartem" (Iza). 23 lipca 2011 roku odbył się pokaz przedpremierowy w stołówce DPS w Jonkowie na otwarcie festiwalu Wioska Teatralna w ramach Mandali otwarcia. Wacław Sobaszek nazwał spektakl „Snem nocy letniej z 1946 roku”, nawiązując do inspiracji, która powstała podczas projektu tworzonego wraz ze studentami teatrologii z Lipska. Pracowano wtedy nad Szekspirem, a równolegle odwiedzano Senioren Haus. Uczestnicy warsztatu spotkali tam panią Gerhardt, która opowiadała o swojej maturze z 1946 roku. Jak napisał mi Wacław Sobaszek: „Atmosfera tamtego przełomowego czasu była bardzo silna, emanowała ze sposobu opowiadania. Próbowałem podsunąć studentom myśl, by robić wspólnie ze studentami taką wizję: Sen nocy letniej $1946^{\circ}$. Projekt ten nie rozwinął się w Lipsku, ale został zrealizowany w DPS w Jonkowie.

Również dla Ireny i Mariusza, ludzi niemal zupełnie niepełnosprawnych fizycznie, poruszających się na wózkach inwalidzkich, twórcy spektaklu znaleźli miejsce, pokazując, jak twórczo można wykorzystać ich chorobę. Ich wózki przystrojono liśćmi, kwiatami, pnączami, gałęziami, wiankami z ziół, czyniąc z nich mieszkańców Lasu Ardeńskiego Hermię i Puka. Tak to, co zwykle jest świadectwem niemocy, stało się elementem znaczącym - kostiumem teatralnym. Irena i Mariusz ustawieni w centrum sceny wokół usypanej z ziół i kwiatów mandali najbardziej przykuwali uwagę publiczności, mimo że przez cały spektakl nie powiedzieli ani słowa. Ze swoją nienachalną, efemeryczną obecnością znakomicie sprawdzili się w roli leśnych duchów.

W spektaklu przyjęto znany z poprzednich schemat - aktorowi Teatru Węgajty zawsze towarzyszył performer z DPS. Jest w nim scena, w której pani Krystyna upada wraz z innymi dziewczynami tańczącymi w korowodzie. Mute Sobaszek podziwiała jej odwagę, ale też obawiała się, że publiczność odbierze to jako sytuację niebezpieczną dla starszej kobiety. Wśród pozostałych członków zespołu pojawiło się jednak zaufanie do performerki, wiara w jej możliwości. Jak mówiła Mute Sobaszek: „Znam ją długo i wiem, że czuje swoje ciało i zrobi to w bezpieczny dla siebie sposób. I wiem, że ona musi najpierw podnieść się sama na czworaka, dopiero potem możemy jej pomóc wstać”. W porównaniu z poprzednimi spektaklami w Śnie nocy letniej było znacznie więcej improwizacji ludzie, którzy trzy lata wcześniej byli przerażeni, że muszą nauczyć się na pamięć kilku wersów z Wesela, zaczęli z ogromną swobodą improwizować i bawić się na scenie. Tym razem, inaczej niż w przypadku poprzednich występów, Halina złapała dystans do formy, nie bała się improwizować, rozgrzewała publiczność. Swoją rolę zbudowała na grotesce i przerysowaniu, które charakteryzują estetykę Teatru Węgajty.

8 Z wymiany e-maili między mną a Wacławem Sobaszkiem z 2 listopada 2012 roku. 
Praca teatralna w DPS to zawsze work in progress - nie można tu mówić o zamkniętej, efektownej całości, precyzyjnym dopracowaniu detali. Scenografia jest efektem hand made, recyklingu. Performerzy i adepci otrzymują od Wacława Sobaszka wiele różnorodnych zadań aktorskich do wykonania - nie chodzi tylko o to, by wcielić się w postać, wypowiedzieć tekst, ale też improwizować, grać na instrumentach, śpiewać, tańczyć. Mieszkańcy porozumiewają się między sobą w trakcie przedstawienia, zerkają w stronę reżysera, rozmawiają z publicznością, szukając aprobaty - teatr przecina się z życiem. Trudno mówić o doskonałości artystycznej, przez co ciężko pracę tę bezdyskusyjnie wpisać w „pole sztuki”. Praca w DPS mieści się bowiem w nurcie „teatru potrzebnego”, jest „więcej niż teatrem”.

W tej pracy zawsze coś się sypie - a to ktoś zapomni tekstu, ktoś inny się przewróci, nie zauważając zmiany sytuacji, ktoś jeszcze inny wyjdzie z roli, by pogadać ze znajomym. Ale przecież „budowanie intrygi nie jest nigdy zwykłym triumfem porządku”, bowiem nawet grecka tragedia zawierała $w$ sobie odmiany losu, takie jak perypetie odpowiedzialne za wyzwolenie litości i trwogi (Ricoeur, 2008a, s. 108). Mieszkańcy DPS wpleceni w tkankę spektakli stanowią moment nieprzewidywalności będący cechą każdej dobrej fabuły, o czym pisze Ricoeur w drugim tomie Czasu i opowieści. Z jednej strony „wielkie narracje" porządkują doświadczenie mieszkańców DPS, z drugiej heterogeniczność i brak spójności jako cechy wyróżniające „litotyczne narracje” mieszkańców DPS, a także sposób zachowania pensjonariuszy wpływają na aleatoryczną formę przygotowywanych spektakli oraz ich patchworkową strukturę. Zarówno Wesele - domena publiczna, jak i Iwona poślubiona to spektakle „na podstawie”, spajające w jedno kilka utworów, tączące je z pieśniami i melodiami ludowymi oraz improwizacjami aktorów. Narracja spektakli teatralnych przygotowywanych przez zespół Hazbeszkwej nie stara się likwidować na siłę niespójności (tożsamej tu z brakiem scenicznego profesjonalizmu), którą wprowadza narracja mieszkańców, stara się je pojednać na poziomie kompozycji spektaklu. Nadaje „litotycznym opowieściom” - które rozumiem tutaj jako tożsame z realnym doświadczeniem mieszkańców - wzorzec narracyjny i porządkuje doświadczenie.

\section{Rozumienie doświadczenia pracy teatralnej przez mieszkańców DPS w Jonkowie}

Do pełni obrazu pracy Teatru Węgajty w DPS w Jonkowie nieodzowne jest przedstawienie rozumienia tego doświadczenia przez mieszkańców oraz uzupełnienia, jaką rolę pełni wielka narracja, przejawiająca się w inscenizacjach Wyspiańskiego, Gombrowicza i Szekspira. Czy pensjonariusze mają poczucie partnerstwa i współpracy? Czy w ich rozumieniu to, co robią, może być atrakcyjne dla innych, czy też robią to wyłącznie dla siebie? Jakie są według nich powody działań Teatru w DPS? Kim w ich oczach są Sobaszkowie? I w końcu: czy teatr jest im potrzebny? 
Część mieszkańców, myśląc o teatrze jako formie sztuki czy instytucji, operuje stereotypami. Ponieważ dla wielu z nich było to pierwsze zetknięcie z teatrem w ogóle, DPS był dla Teatru terenem dziewiczym. Dla ludzi ubogich, z niskim wykształceniem, wiejskim pochodzeniem, teatr jest rozrywką raczej niedostępną, ekskluzywną, zdarzającą się okazjonalnie - w postaci teatru objazdowego czy obrzędowego. Jak wynika z przeprowadzonych przeze mnie wywiadów, potrzeby kulturalne mieszkańców DPS zaspokaja przede wszystkim telewizja, muzyka, rzadziej kino.

Obecność Teatru w DPS oceniana jest jednoznacznie pozytywnie - zwłaszcza przez aktywnie biorących udział w pracy teatralnej. Goście z Węgajt wyczekiwani byli z utęsknieniem: „Zawsze czekamy na nich, zawsze się cieszymy, wiemy, że coś się będzie działo. Jest fajnie” (Iza). Teatru w DPS jest jednak ciągle za mało, „od przypadku do przypadku coś robią” (Artur). Teatr jest „spontaniczny, otwarty” (Barbara), a zatem zupełnie inny niż otoczony zasiekami DPS. Oprócz mieszkańców będących aktorami jest jeszcze drugi plan, czyli publiczność - odbiorcy tego, co pokazuje teatr i ich koledzy. Tych ludzi również pytałam o stosunek do odbywającej się w DPS pracy teatralnej. Według nich zespół Hazbeszkwej „ciężko pracuje” (Dominik). Kiedy pojawia się wieść, że przyjeżdża teatr, w DPS panuje wielkie poruszenie. Z drugiej strony wiele jest przykładów zobojętnienia - wszak wielu z moich rozmówców to ludzie trwale unieruchomieni z powodu schorzeń, starości, braku sensu życia, świadomości zbliżającej się śmierci, jak Pani X. „Co ja tera mogę sądzić? Jak ja myślę o dole, a nie o górze? [...] Nie mam pamięci, żeby cokolwiek robić..." (Pani X). Choć stosunek do teatru jest raczej pozytywny, nie postrzegają go jako rodzaju terapii, zwłaszcza kiedy uczestnictwo w niej uniemożliwia kalectwo: „Lubię, lubię te ich zabawy. Tylko nogów nie mam - nie chodzę" (Pani X). Niektórzy z nich początkowo żartowali na temat udziału w pracach teatralnych swoich kolegów z DPS, traktując to jako bezsensowne wygłupy, czasem odnosząc się wręcz z wyraźną niechęcią [„A na co tu patrzeć? Na głupią Barbarę?!" (Pani X)]. Z czasem jednak zaczęli doceniać współmieszkańców: „Mają trochę talent. Biorą udział, chcą, to trzeba ich wzmacniać, dobrze, że czymś się zajmują w ogóle. Bo tutaj można tylko siedzieć i telewizję oglądać, radia słuchać, a tak zawsze jest jakieś zajęcie” (Dominik).

Członkowie Hazbeszkwej traktują pracę z teatrem jako rozrywkę, zabawę, połączenie przyjemnego z pożytecznym, sposób przełamania monotonii codzienności, a czasem jako wielką przygodę, odkrywanie nieznanego lądu (Iza); inni jako ważną zmianę prowadzącą do poprawy losu: „Nigdy nie podejrzewałam, że mam talent aktorski. [...] Państwo z Węgajt odkryli we mnie talent aktorski i porwali mnie do siebie. [...] Bardzo spodobało się, że śpiewałam, zwłaszcza że do tej pory byłam bardzo zamknięta, milcząca. Akurat była taka uroczystość - kolędowanie i ja zaśpiewałam tę kolędę. I pan Wacław powiedział: «0, tu mamy następną aktorkę». I od tego momentu zaczęłam myśleć: dlaczego ja nie śpiewam?" (Barbara). Praca teatralna pozwala jej poczuć pełnię życia, oddychać pełną piersią: „[...] tutaj, jak zaczęłam grać, to dopiero czuję się jak w swoim żywiole. Czuję się bardzo szczęśliwa i spełniona” (Barbara); a wręcz pozwala przywrócić sens życia: „Teatr 
Węgajty jest naszą jedyną rozrywką i ostoją. I to jest czymś wspaniałym, niespotykanym. Teatr Węgajty jest moim sensem bycia” (Barbara). To także ratunek przed pustką: „Wiem już, że nie będę miała więcej pustych dni. Ile można czytać, oglądać telewizję?". Słowa Barbary skomentował Wacław Sobaszek, dając do zrozumienia, że takie myślenie należy traktować z przymrużeniem oka, jako bezpieczną fikcję: „[...] to zabrzmiało bardzo dobrze. I ja to uznaję. Tu trzeba by myśleć i działać w tym kierunku, żeby to nie było rodzajem uczepienia się ramienia kogoś, wtedy to się stanie fałszywe. Ale w tym momencie to jest piękne. Dla kogo Teatr Węgajty ma być sensem życia jak nie dla takich ludzi? Niech sobie właśnie robią takie utopie. Oni tego potrzebują, w DPS panuje pustka”. Bezpieczne, zdystansowane podejście ma z kolei Iza: „W wolnych chwilach nudzenia się mam ten czas niewykorzystany, to kładę sobie tekst na kolana i się uczę. Nie jest tak, że muszę się nauczyć tekstu. Traktuję to jak przerywnik. Może to śmiesznie brzmi, ale tak właśnie jest. Nie chcę się angażować wielce, nie chcę być wielkim aktorem, tylko po prostu traktuję to jak przygodę. [...] To była komedia, więc można było się troszkę powygtupiać " (Iza).

Dzięki pracy teatralnej Barbara z DPS wciela się nie tylko w rolę przewidzianą dla niej przez reżysera, ale też przyjmuje rolę, jakby powiedział Georges Gurvitch: „niespodziewaną, upragnioną, lecz nie realizowaną, nieraz jedynie wymarzoną" w odróżnieniu od jej codziennej roli społecznej: osoby wykluczonej, chorej, mieszkanki DPS, czyli „roli statutowej, formalnej, zwyczajowej, narzuconej” (Gurvich, 1987, s. 37). Praca teatralna staje się dla niej sublimacją pewnych pożądanych sytuacji społecznych.

Stosunek Barbary do innych mieszkańców udzielających się w Hazbeszkwej jest chłodny albo wręcz wrogi. Teatr Węgajty to dla niej wysłannicy lepszego świata. Na jej przykładzie widać, że istnienie zespołu Hazbeszkwej jest ignorowane - nawet jego członkowie z grona pensjonariuszy utożsamiają się z Teatrem Węgajty, czując się wpisani w jego historię i poetykę. Również niewielu pensjonariuszy-obserwatorów zdaje sobie sprawę z istnienia tego zespołu jako osobnego, autonomicznego tworu. Sytuację tę tłumaczy Iza: „No bo tu niewiele się mówi o tej nazwie - to my podciągnięci pod Teatr Węgajty” (Iza). Praca z Teatrem Węgajty wyzwala poczucie przynależności do innej wspólnoty niż DPS-owska zbieranina.

Pytałam pensjonariuszy, dlaczego Sobaszkowie pracują w DPS. Moi rozmówcy zdają sobie sprawę, że robią to, by pomóc ludziom, których darzą sympatią, a widząc, że cierpią, "chcą ich pocieszyć” (Pan Y i Tomasz). Teatr „chce, abyśmy mieli jakieś zainteresowanie, zajęcie, nie tylko cztery ściany. Żebyśmy sprawdzili się, że coś jeszcze możemy zrobić. [...] Ale wydaje mi się, że wiedzą, że ludzie tutaj są... no może nie biedni, ale z bagażem doświadczeń. I że może jeszcze im się w życiu coś należy. I dlaczego nie spróbować ich jakoś zainteresować” (Iza).

Ale kim tak naprawdę są ci „wspaniali ludzie”, z którymi „przyjemnie się rozmawia” (Pan Y i Tomasz) - nie wiadomo. Poza Izą żaden z pensjonariuszy nie wiedział nic na temat ich pochodzenia, biografii, codziennej pracy liderów Projektu Terenowego. Teatr spełnia 
tutaj wyraźne funkcje utylitarne. Jest szansą na wyrwanie się z monotonii codzienności. Pozwala ćwiczyć sprawność fizyczną i intelektualną, w tym pamięć; przełamuje rezygnację, przywraca możność i wiarę w sens działania: „Myślałam, że w takim stanie chorobowym, w jakim jestem, nie jestem w stanie wiele wykrzesać z siebie. A jednak można. [...] No ale jak się znalazłam $w$ tym domu, to przecież trzeba było coś ze sobą zrobić. [...] Inaczej człowiek zaczął myśleć, inną potrzebę ma: sprawdzenia się i po prostu ćwiczy pamięć, nie jest zaszufladkowany, że tylko to, to i to" (Iza). Dzięki odwiedzinom Teatru można poznać ludzi i „oderwać się od towarzystwa” (Artur). Ważna jest więc interakcja z publicznością, która umożliwia wpisanie we wspólnotę komunikacyjną szerszą niż zamknięta, duszna społeczność, w której przebywają na co dzień. Publiczność DPS w dużej mierze stanowią bliscy i rodzina mieszkańców - a spektakl z udziałem pensjonariuszy daje powód do częstszych odwiedzin, być może nawet napawa dumą i podziwem dla performerów. Najbardziej zaskakująca była wypowiedź Tomasza, cierpiącego na porażenie mózgowe i jeżdżącego na wózku, który powiedział: „Dowiedziałem się, że potrafię tańczyć" (Tomasz). Pensjonariusze zdają sobie sprawę, że daleko im do doskonałości i artystycznej precyzji, że efekty ich pracy są ułomne i nie można od nich wymagać perfekcji.

Nie wszyscy mieszkańcy potrafili rozpoznać i nazwać inność Teatru Węgajty. Łatwiej przychodziło to ludziom z większym „kapitałem kulturowym”. Jedna z mieszkanek, chora „somatycznie”, z wykształceniem średnim ekonomicznym, zapytana o specyfikę Teatru Węgajty odpowiada: „Jest to na pewno teatr inny, specyficzny. No i stąd może nazwa teatru - wiejski. W mieście inaczej wygląda teatr. A ten jest bardzo prosty, oparty na prostocie" (Iza). Z kolei mieszkaniec chory na porażenie mózgowe, z wykształceniem podstawowym, na to samo pytanie odpowiada: „Ja myślę, że nic go nie wyróżnia. Oni po prostu lubią swoją pracę” (Tomasz). Na pewno zaskakuje jego „naturalność” (Barbara), za rozpoznaniem której szła również głęboka świadomość powinności aktorsko-performerskich: „Po prostu trzeba dać z siebie wszystko. Nie być sztucznym. Tak jak się to czuje, tak się gra” (Artur). Ci, którzy potrafili zdefiniować specyfikę Teatru Węgajty, nie mieli również większych trudności w rozpoznaniu fundamentalnych dla „trzeciego teatru” strategii: rozbijania typowej relacji widz-aktor [„Oni, jak to się mówi, wychodzą naprzeciw ludziom” (Dominik)], budowania wspólnotowości [„My zaczęliśmy się już bardzo rozumieć. Czasami to zrozumienie jest podstawą bycia ze sobą" (Barbara)], poszerzania przestrzeni teatralnej [„Gra głosów - brzmi inaczej niż tutaj. Tutaj jest tyle drzwi, jeden chodził, drugi wychodził. A tam jest cisza, spokój. Tam jest inaczej, ale też na dworze jest inaczej. Posłuchać jeżdżące auto. To też ma swój urok w plenerze. Wystawienie w teatrze, w plenerze, a tutaj w stołówce było całkiem inne"(Iza)] oraz jego społecznej, animacyjnej funkcji [„Wydaje mi się, że wiedzą, że ludzie tutaj są... no może nie biedni, ale z bagażem doświadczeń. I że może jeszcze im się w życiu coś należy" (Iza)].

Paul Ricoeur napisał, że „zrozumieć, czym jest opowieść, to opanować reguły rządzące jej syntagmatycznym porządkiem" (Ricoeur, 2008a, s. 86). Ci, którzy opanowali treść i formę opowieści Gombrowicza, Wyspiańskiego i Szekspira („reguły kompozycji”), bez trudu 
odnajdują sensy, jakie nakładają one na przedrozumienie działania mieszkańców DPS. Jednak wielu spośród mieszkańców nie dostrzega tych subtelności. Czy doświadczenie mieszkańców DPS posiada jakieś adekwatne w kulturze opowieści? Czy przedstawione wyżej „litotyczne narracje” czerpią wzorce z opowieści Wyspiańskiego i Gombrowicza? Czy w jakikolwiek sposób są one konstytutywne dla ich tożsamości? Wywiady dotyczące Wesela i Iwony poślubionej dowiodły, że wśród mieszkańców pojawia się trudność w rozumieniu bardziej zawoalowanych sensów, w wyodrębnieniu i interpretacji środków wyrazu (mimo że spektakle są zwykle bardzo proste formalnie), wynikająca z nieznajomości literatury oraz tradycji i estetyk teatralnych, w ramach których działa Teatr Węgajty. Nieuchwytne pozostaje dla nich subtelne wplecenie w treść opowieści charakterystyk ich samych. Dramat Wesele powszechnie budzi skojarzenia z lekturą ze szkoły średniej. Jest świadomość, że tekst napisał Wyspiański (w opinii Artura „pijak i weneryk”) i że „jest to nadzwyczajna, ciekawa sztuka, a jednocześnie trudna" (Barbara). Doceniana jest doniosłość dramatu: „Młoda Polska to jest fenomen dziejowy. A Wesele to jest następny fenomen" (Barbara). Natomiast to, co z tym zrobiono, sensy pozostają raczej niejasne, bądź są spłycane: „Chodziło po prostu o to, jak się ludzie na wsi bawią. Jak wygląda wesele i jak to przebiega” (Iza). Wiadomo, że Wesele zostało „bardzo wycinkowo potraktowane, epizodycznie i takie jest wspaniałe. [...] Jest tutaj przedstawione tak wspaniale, naturalnie, lekko" (Barbara). Zdjęty został ciężar szkolnej lektury, chociaż sens przedstawienia ogranicza się wciąż do szkolnych interpretacji: „Poeta Rydel wziął sobie za żonę prostą wiejską dziewczynę. Wówczas to było traktowane jako ogromny mezalians. Teraz to jest na porządku dziennym" (Barbara). Moi rozmówcy często mówili o mezaliansie jako wątku silnie obecnym w dramacie Wyspiańskiego, będącym zarazem zaobserwowaną przez nich wyrazistą zmianą obyczajową, jaka dokonała się w toku ich życia: „Były młode, przystojne i rzucały wszystko, byle jedno drugie zdobyć. Jak jedno drugiemu się podobało, to nie było silnych" (Pani Q). Pojawiają się więc odniesienia do współczesności i rozumiana jest aktualność tego dramatu także dzisiaj: „Powiem lapidarnie: zawsze będzie aktualne. Chociażby te mezalianse..." (Barbara). Rozmówcy pytani o Wesele nie odnoszą się do dramatu ani nawet do spektaklu, lecz do własnych doświadczeń, jak Pani Q, która, rozmawiając ze mną, przekazała szczegółowy obraz wesel z czasów młodości. Sens Iwony poślubionej w rozumieniu mieszkańców uobecnia się na poziomie intrygi i psychologii: „No taka prosta dziewczyna, z której książę robił sobie żarty i finałem tych żartów była śmierć tej Iwony. On sobie cały czas żartował, dowcipkował, a ona brała to na poważnie. A w międzyczasie też miała romans. I niestety wszystko wyszło na jaw i oceniła że musi sama skończyć z sobą i nie czekać na tego karasia i samej się otruć" (Iza). Mieszkańcy wyczuwają, że Iwona i Ślub to utwory gorzkie i niejednoznaczne: „Niby to jest komedia, ale to się właściwie dramatycznie kończy” (Iza). Do postaci, które grają, porównują się więc w sposób nieświadomy.

Wesele poniekąd było spektaklem autotematycznym - krytykującym bezrefleksyjne podejście do tradycji, zachwyt wsią traktowaną jako kolebka autentyczności. Ten wątek również pojawia się w wypowiedziach mieszkańców: „Chłopki były naturalne, inne. No 
tylko że jest oczywiście różnica poziomów kulturalnych. Ale jak ktoś był zakochany, to nie widział tego" (Barbara). Naturalność i inność jest również tym, co przyciąga Teatr Węgajty do mieszkańców DPS, choć owa „różnica poziomów kulturalnych” zawsze będzie stanowiła barierę.

Jak pisał Jean Améry: człowiek starzejący się ani nie potrafi zrozumieć, ani się poruszać w otaczającej go kulturze, a kody, którymi czytał ją dawniej, okazują się bezużyteczne (Améry, 2007). Jego tragizm polega na tym, że odrzucając współczesną kulturę, stanie się outsiderem, zaś przyjmując ją bezkrytycznie, stanie się nieautentyczny. Kultura jest więc dla starzejącego się człowieka kolejną udręką, zaprzeczeniem własnego ja. Doświadczenie, w którym uczestniczą mieszkańcy DPS, nie może więc być przez nich w pełni zrozumiane i przyjęte. To, co narzucają wielkie narracje Wyspiańskiego, Gombrowicza, Szekspira, jest z ich perspektywy „gwałtem interpretacji”, jednym z przejawów ich „anty-ja”. Dla Tomasza Sen nocy letniej to po prostu „opowieść o życiu” (Tomasz). Nie znaczy to jednak, że wysyłane przez Teatr Węgajty komunikaty są mieszkańcom obojętne. Interpretują je bowiem na swój sposób, odnosząc do własnego kontekstu, własnej rzeczywistości. Może mieszkańcy DPS wcale tych wielkich sensów nie potrzebują: „Aż tak głęboko nie wchodziłam w Wesele. Dlaczego? Bo w ubiegłym roku grałam jeszcze w Zielonej gęsi Gałczyńskiego i nie miałam czasu zagłębiać się w inne role..." (Barbara). W tym aspekcie stają się performerami w rozumieniu Jerzego Grotowskiego - istotami zorientowanymi na działanie, a nie refleksję. 


\section{MIMESIS III, CZYLI ZAKOŃCZENIE}

Dlaczego jeden z pierwszych w Polsce teatrów antropologicznych, wywodzący się w pierwszej linii ze schedy Jerzego Grotowskiego, interesuje się czymś tak ułomnym, słabym, amatorskim? Odpowiedź odnaleźć można u Michela de Certeau, dla którego istotną inspiracją byli sofiści - prekursorzy taktyk - którzy mieli zasadę, by „najsilniejszym” uczynić argument „słabszy” i „twierdzili, że posiedli sztukę odwracania władzy przez wykorzystanie sposobności" (Giard, 2008, s. XLIII). Interesowała ich, podobnie jak de Certeau, „inteligencja i pomysłowość najsłabszego”, przejawiali „szacunek wobec słabego, pozbawionego mienia i miejsca, i wykazującego z tego powodu elastyczność wobec strategii silniejszego" (Certeau, 2008). Perspektywę tę można przełożyć na relację „narracji litotycznej” i „wielkiej narracji”. Słaby, który przejawia się w „litotycznej narracji”, ma zdolność infekowania, ingerowania w „wielką narrację”, za którą uznać można tradycję teatralną Teatru Węgajty, jak również całą tradycję teatru antropologicznego. Ta pozbawiona waloru nowości, oryginalności, spójności mała, kaleka narracja ma istotną rolę w „odnawianiu znaczenia” „wielkiej narracji”, nadaje jej nowy wymiar i kontekst.

Z drugiej strony jest narracja Teatru, która posiada wartość ocalającą poprzez możliwość opowiedzenia na nowo tekstu życia mieszkańców DPS - czy to poprzez zakamuflowane opowiadanie epizodów z ich życia w spektaklach, w kręconych filmach, czy podczas spotkań z publicznością. Ponieważ wspólne wszystkim mieszkańcom DPS jest przeżycie traumy, to działalność Teatru Węgajty w tym aspekcie „pomaga ponownie w jakimś sensie zintegrować to, co niewyrażalne" (Budziszewska, 2007, s. 25). Opowiadanie, śledzenie i rozumienie „litotycznej narracji”, zapośredniczonej przez „wielkie opowieści” Wyspiańskiego, Gombrowicza i Szekspira „to tylko kontynuacja owych niewypowiedzianych historii” (Ricoeur, 2008a, s. 111). Teatr Węgajty daje mieszkańcom DPS szansę na poradzenie sobie z kryzysem tożsamości, pozwala na jej rekonstrukcję. Spełnia funkcję „wielkiej narracji” w tym sensie, że wpływa na sposób przeżywania i rozumienia zdarzeń z własnej biografii, mimo że - jak wykazały moje badania - nie spełniają tej funkcji dzieła Gombrowicza i Wyspiańskiego. Ponadto opowiadanie o mieszkańcach DPS i angażowanie ich do spektakli będące „obroną całkowicie nieuformowanego czasowego doświadczenia” (Ricoeur, 2008a, s. 108) jest przejawem przynależnej estetyce i poetyce teatru Gombrowiczowskiej fascynacji brakiem formy. Teatr Węgajty włącza „litotyczne narracje” mieszkańców DPS we własną narrację - narrację jednej z czołowych grup teatru antropologicznego. Pensjonariusze stają się istotnym elementem historii Teatru i jego dorobku. Jak zostało pokazane wyżej, część mieszkańców uważa się za członków Teatru Węgajty. Teatr jest dla nich rodzajem „wielkiej narracji”, w której się przeglądają, którą pragną dzielić.

„Opowieść bowiem ma swój pełny sens, gdy zostaje przywrócona do czasu działania i doznawania w mimesis III” (Ricoeur, 2008a, s. 106) - czyli w przecięciu świata tekstu i świata słuchacza lub czytelnika, w Gadamerowskim „stapianiu się horyzontów” (Gadamer, 1993, s. 286). Owo przecięcie dokonuje się wraz z lekturą - w tym wypadku wraz 
z uczestnictwem w spektaklach zespołu Hazbeszkwej: „Akt lektury jest zatem operatorem, który łączy mimesis III z mimesis II". Lektura aktualizuje opowiadaną historię, a także dopowiada do niej sensy. Zwłaszcza że tekst - „litotyczne opowieści” mieszkańców DPS wpisane w „wielkie narracje” - sam w sobie zawiera wiele luk i niedookreślonych miejsc. Jak wygląda zlanie się horyzontów, proces „refiguracji”? Jako czytelnicy opowieści mieszkańców DPS, pełnych pustych miejsc, niedopowiedzeń, nieciągłości, Sobaszkowie dokańczają ich dzieło w sensie Ricoeurowskim.

Praca z mieszkańcami na początku miała cel etnograficzny - podczas warsztatu Przetwarzanie pamięci wyraźnie mówiono jego uczestnikom, że chodzi o odtworzenie obrazu dawnej potańcówki. A zatem o poszukiwanie „wielkiej narracji”, spójności, jedności doświadczenia, którego jednak nie odnaleziono w tak heterogenicznym miejscu, jakim jest DPS. Ale co zrobić z tym zebranym, ułomnym materiałem? Zapomnieć, odłożyć, przestać się interesować? Z czasem zaczęło chodzić o coś więcej niż o „wielką narrację” - artyści zrozumieli, że te „litotyczne”, znikome, zupełnie niespektakularne opowieści mieszkańców są równie warte ocalenia. Okazało się, że codzienność, zwyczajność jest „usiana cudami, równie migotliwymi [...] jak blask pisarzy czy artystów” (M. de Certeau, La Culture au pluriel, wyd. 2, ss. 244-245, cyt. za: Giard, 2008, s. XIX).

Działalność Teatru Węgajty pozwala oglądającym spektakle Hazbeszkwej zrozumieć element spajający, a zarazem kończący „litotyczne opowieści” - bezwolne trwanie i skazanie na DPS. Przy czym dominującym uczuciem na widowni niekoniecznie musi być wspótczucie i spolegliwość, czyli taryfa ulgowa, jaką zwykle obdarza się niepełnosprawnych i wykluczonych. Mute Sobaszek w rozmowie ze mną określiła to jako proces „obiektywizowania się spektaklu", czyli wyzwolenie u widza koncentracji na treści, a nie formie. Komunikacja między performerami z grona Hazbeszkwej a publicznością dąży do ideału komunikacji „multiwersalistycznej”, komunikacji nieskończonej rozmowy, która potrzebuje i chroni inność innego (Marquard, 1994, s. 76). Jeśli oglądanie spektakli zespołu Hazbeszkwej tożsame jest z procesem lektury, to dzieło, jakim są „litotyczne opowieści” mieszkańców DPS, wchodzi dzięki owemu procesowi lektury w obszar komunikacji i odniesienia do rzeczywistości. Tym samym mieszkańcy wpisani zostają ponownie we wspólnotę komunikacyjną, łączą się z innymi poprzez „internarracyjny splot” (Budziszewska, 2007). O ile symptomatyczna dla mieszkańców DPS jest niemożność działania, czyli cierpienie, o tyle praca z Teatrem Węgajty uruchamia w nich potencjał działania; jak zauważył Ricoeur - wszak działanie jest zawsze „działaniem-z-innymi”. Działanie owo przybiera formę „współdziałania” - w odróżnieniu od rywalizacji i walki, jakie toczą mieszkańcy DPS nawzajem i z personelem.

Jak zauważył Jean Améry, w starzejącym się człowieku istnieje ja wolne od sprawiającego ból, ciążącego ciała - ja duchowe, które „jest czasem przeżytym we wspomnieniu” i jako takie walczy z przejęciem całego ja przez physis. Jest również „ja społeczne”, które istnieje poprzez interakcję z innymi i realizuje się w działaniu. O ile Améry twierdzi, że człowiek stary pozbawiony jest „możliwości dysponowania sobą, zaczynania w każdej 
chwili od zera, projektowania swojego życia na podstawie własnej woli” (Améry, 2007, s. 75), to w przypadku mieszkańca DPS ową emanacją innego ja, negocjującego wiek i werdykt społeczny, walczącego z ciałem, jest „ja teatralne”.

\section{Teatr Węgajty na tle tradycji teatru antropologicznego}

Wśród teatrów pracujących na wsi często można spotkać się z młodopolskim, romantycznym stosunkiem do kultury lokalnej, fascynacją „autentycznością, prostotą reakcji”, jak powiedział Grzegorz Artman po pokazie filmu Filiżanka 18 maja 2010 roku w Instytucie Teatralnym. Działanie na prowincji i dla prowincji ufundowało „trzeci teatr”, który „żyje na marginesach, często na zewnątrz lub na obrzeżach centrów i stolic kulturalnych" (Barba, 2003, s. 207). Osiedlanie się na prowincji stało się wyróżnikiem polskiego teatru antropologicznego. Prowincja i kultura tradycyjna w czasie, kiedy powstawał, była „ożywającym, nadającym sens centrum” (Jawłowska, 1988, s. 6), „utraconym rajem” (Jawłowska, 1988, s. 7), który odnaleziono w czasach nieprzyjaznego kulturze PRL i wokół którego próbowano budować kulturowy ład. Teatr Węgajty/Projekt Terenowy i Schola Teatru Węgajty zdają się pod tym względem teatrami najsilniej i najdłużej wrośniętymi w prowincję, a zarazem najdotkliwiej odczuwającymi pogorszenie stosunków z nią, jeśli jeszcze nie definitywne rozstanie. Na ten temat powstała niepublikowana praca doktorska Olgi Kwiatkowskiej Obraz nieopisany. Wizerunek nowoosadników w perspektywie spoteczności lokalnej. Co ciekawe, badania Kwiatkowskiej prowadzone były w grudniu 2006 roku, czyli kilka miesięcy po incydencie rasistowskim ${ }^{10}$. Wynika z nich, że - mimo niemal trzydziestoletniego sąsiedztwa - działający na terenie wioski teatr ciągle postrzegany jest jako obcy, nieznany, a czasem wręcz szkodliwy i wrogi. Badani (mieszkańcy wsi Węgajty) wyraźnie rozgraniczają przestrzeń wsi Węgajt - „u nas”, od przestrzeni zaadaptowanej przez teatr, która znajduje się „w lesie”, „u nich”, gdzie rzadko się zagląda. Ci „z lasu” to tak zwani teatralni, różniący się ubiorem, stylem życia i rodzajem diety. Lokalna społeczność nie interesuje się działaniami teatru, czas wypełniają jej głównie prace gospodarskie i najprostsze formy rozrywki np. telewizja. Zainteresowanie teatrem malało z czasem - na początku miejscowi chętniej chodzili „do lasu” przyciągnięci nowością zjawiska. Powody spadku zainteresowania wiążą się, według badań Olgi Kwiatkowskiej, z rosnącą hermetycznością, niezrozumiałością spektakli, a także ze wspomnianą już dostępnością innych, łatwiejszych rozrywek: „Teatr się ludziom znudził, przestał być ciekawostką, wiedzieli już,

9 Filiżanka to artystyczny film dokumentalny w reżyserii Grzegorza Artmana, Armanda Urbaniaka i Agnieszki Bojanowskiej, pokazujący objazd spektaklu Hotel pod Aniołem po małych miejscowościach i wsiach województwa świętokrzyskiego.

10 Szeroko opisywany w prasie incydent rasistowski, któremu poświęciłam jeden z podrozdziałów pracy magisterskiej, miał miejsce w nocy z 22 na 23 lipca 2006 roku we wsi Węgajty. Brutalnie pobito czterdziestotrzyletniego Marokańczyka, Abdela Mandili, członka grupy teatralnej, dyrektora artystycznego Migrator Theatre ('Teatr Migranta'), pokazującej tego wieczora widowisko Rasa pieczatek Simona Mola. Ataku dokonało dwóch mieszkańców miejscowości Ramoty i Pelnik, oddalonych o kilkadziesiąt kilometrów od Węgajt. Incydent przerwał festiwal Wioska Teatralna. W kwietniu 2007 roku sąd ostatecznie uznał, że atak na Abdela Mandili był pobiciem na tle rasistowskim. Powaga wyroku ucierpiała ze względu na sprawę samego Simona Mola, dyrektora artystycznego Migrator Theatre, z początku 2007 roku. Incydent rasistowski doprowadził także do pogorszenia stosunków między mieszkańcami Węgajt a artystami, którym zarzucano szkalowanie wsi. 
czego się mogą po jego sztukach spodziewać, i nie było to dla nich atrakcyjne. Ponadto, dawniej Teatr był jedną z niewielu dostępnych miejscowym formą rozrywki, a teraz mają do dyspozycji wielokanałową telewizję, wielu ma też już dostęp do Internetu" (Kwiatkowska, 2008, s. 234). W skrajnych przypadkach uczestnictwo w spektaklach stanowiło dla lokalnych dyshonor \{,jak by ktoś poszedt [na przedstawienie] i znajomy by to usłyszał, to by powiedział: głupi jesteś" (Kwiatkowska, 2008, s. 235)\} i przekształcało się w alkoholową libację: „Ich celem była zabawa według własnego scenariusza, spektakl stanowit jedynie jej tło" (Kwiatkowska, 2008, s. 235). Mieszkańcy Węgajt mają świadomość, że to nie oni są odbiorcą przygotowywanych przez Teatr wydarzeń, że są one skierowane do mieszkańców miast i miłośników teatru: „z Teatrem w Węgajtach jest tak, jak z Radiem Maryja w Toruniu, mieszkańcy Torunia tam nie chodzą, a ludzie z zewnątrz przyjeżdżają” (Ewa); „przyjeżdżają przeważnie [osoby] z ich towarzystwa [artystów - O.K.], więcej uczone ludzie, profesorowie czy inni, z Warszawy tam przyjeżdżają, i z tych wszystkich tych okolic, gdzie one są [warszawiacy] pochodzenia żydowskiego (wyw. 1W; wyw. 18W)" (Kwiatkowska, 2008, s. 236).

Przykłady otwartej niechęci, która wzrosła pod wpływem incydentu rasistowskiego, można by mnożyć. Lokalni mieszkańcy nie mogą na przykład zrozumieć, że „teatralni” nie używają alkoholu, i twierdzą, że muszą w takim razie brać narkotyki dużo bardziej szkodliwe niż alkohol. O społeczności skupionej wokół teatru mówiono nawet „wioska ćpunów”: „twierdzili, że teatralni często znajdują się pod wpływem substancji odurzających, co łatwo można rozpoznać po ich oczach, ruchach i zachowaniu. [...] Stąd brały się - wspomniane już przeze mnie - obawy dotyczące posyłania dzieci do Teatru, czy pewna nieufność wśród niektórych mieszkańców w stosunku do napojów serwowanych przez teatralnych podczas imprez z obawy, czy aby coś nie zostało do nich dosypane" - pisze Olga Kwiatkowska (Kwiatkowska, 2008, s. 237). Wspominałam również o „podejrzewaniu warszawiaków o żydostwo”; z całą pewnością nie są „czystymi Polakami”. Olga Kwiatkowska przedstawia zaskakujący wniosek odnośnie „żydostwa Sobaszka”: „podstawą do kwestionowania jego polskości a jednocześnie dowodem jego żydowskości są przede wszystkim jego doskonała znajomość języków obcych oraz wysoki poziom inteligencji" (Kwiatkowska, 2008, s. 237).

Grupy pokrewne Projektowi Terenowemu i Scholi, działające w estetyce teatru antropologicznego, takie jak Ośrodek Praktyk Teatralnych Gardzienice, Stowarzyszenie Teatralne Chorea, Ośrodek Pogranicze w Sejnach, Teatr Cinema w Michałowicach, Stacja Szamocin, Klinika Lalek czy Teatr Wierszalin również dzielą doświadczenie rozczarowania prowincją i polską kulturą tradycyjną ${ }^{11}$. W głośnym wywiadzie dla „Gazety Wyborczej” z 2009 roku Włodzimierz Staniewski, dyrektor artystyczny Gardzienic, klęską na prowincji tłumaczył swoją ucieczkę do miasta:

„Roman Pawłowski: Co się zmieniło na prowincji, że wraca pan do centrum? Włodzimierz Staniewski: Społeczna mentalność. Prowincja znów jak za czasów PRL-u staje

11 Wyjątkiem jest Teatr Pieśń Kozła, który od początku działa we Wrocławiu. 
się rozsadnikiem parafiańszczyzny i stereotypów, które, wydawało się, dawno odrzuciliśmy. Zmienia się zresztą nie tylko prowincja - mam wrażenie, że w całym kraju następuje degrengolada aspiracji społecznych i zawężenie myślowych horyzontów. Nie myśli się w kategoriach długofalowych działań, ale doraźnych i przyziemnych. W efekcie coraz trudniej jest działać na światową skalę, operując na prowincji, jak to czyni od lat mój zespół. [...] Było jak w starożytnym teatrze - kiedy coś się podobało, to wynoszono nas na nieboskłon, byliśmy apostołami i aniołami, kiedy jednak się nie podobało, reagowano bezceremonialnie, pędzono nas z wioski z okrzykami: «Krzyże nam tu będą palić!»” (Staniewski, 2009).

Niechęć lokalnego środowiska i ulegające mu władze samorządowe spowodowały utrudnianie i znaczne opóźnienie renowacji zabytkowego kompleksu pałacowego, w którym siedzibę swoją miał teatr: „Nasze wnioski o unijne środki na budowę centrum kultury zostały utrącone mimo wysokich ocen ekspertów. A jednocześnie ożywiła się miejscowa chuliganeria. Ile razy można się bronić? Powtarzam - chciałem być redutą teatru, ale nie Redutą Ordona" - podsumowuje Staniewski (Staniewski, 2009). Szef Gardzienic przyczyn tymczasowej wyprowadzki teatru z podlubelskiej wsi szuka przede wszystkim w niechęci lokalnej społeczności: „To nie myśmy pobłądzili, to mentalność polska się cofnęła. Mam dość bycia żydem, masonem, cyklistą, sekciarzem, manipulatorem. Nie chcę, aby ktoś ciągle rzucał na naszą działalność jakieś czarne zaklęcia” (Staniewski, 2009).

Innym przykładem konfliktu między teatrem działającym na prowincji a lokalną władzą jest protest radnych z ramienia Ligi Polskich Rodzin (w 2005 roku) wobec rzekomo bluźnierczych treści zawartych w spektaklach Teatru Wierszalin z Supraśla (województwo podlaskie), zwłaszcza w Proroku Ilji: „Bohaterowie Proroka llji bez skrupułów nalewali do liturgicznych kielichów wódkę i, powtarzając słowa wypowiedziane przez Chrystusa «Jedzcie i pijcie», wypijali trunek, by po tym przeistoczeniu uprawiać nierząd i kojarzyć brak erekcji z brakiem zmartwychwstania” (,LPR protestuje ws. Teatru Wierszalin”, 2005) ${ }^{12}$. Protesty miały na celu niedopuszczenie do upaństwowienia dotąd prywatnego teatru i przyznania mu dotacji ze strony województwa. Protest zyskał wymiar ogólnopolski po premierze Ofiary Wilgefortis. Tym razem senatorzy LPR z Janem Szafrańcem na czele zaapelowali do ówczesnego Ministra Kultury i Dziedzictwa Narodowego, Kazimierza Ujazdowskiego, by nie przyznawat Wierszalinowi statusu instytucji narodowej i, co za tym idzie, obiecanej dotacji. Oświadczenie popierające list Szafrańca podpisało 22 grudnia 2005 roku szesnastu senatorów z różnych partii: LPR, Samoobrony, Prawa i Sprawiedliwości oraz Polskiego Stronnictwa Ludowego. Sprawa dotacji wisiała na włosku, jednak ostatecznie Teatr Wierszalin funkcjonuje obecnie jako wojewódzka samorządowa instytucja kultury współprowadzona przez Ministerstwo Kultury i Dziedzictwa Narodowego. Warto podkreślić, że te hamujące, barbarzyńskie posunięcia wobec kultury miały miejsce w 2006 roku.

Poza rozczarowaniem polską wsią i kulturą lokalną polski teatr antropologiczny zmaga się z nietrwałością zespołu aktorskiego i atomizacją grup: Teatr Wiejski Węgajty rozdzielił

12 Cytowana wypowiedź (jak wiele innych w podobnym duchu) znalazła się także w liście otwartym senatora LPR Jana Szafrańca z 15 grudnia 2005 roku do Ministra Kultury i Dziedzictwa Narodowego, Kazimierza Ujazdowskiego. 
się w połowie lat dziewięćdziesiątych na Scholę i Projekt Terenowy; w 2003 roku odeszli z Gardzienic Tomasz Rodowicz i Maciej Rychły, zakładając Stowarzyszenie Teatralne Chorea. Po tym jak z Projektu Terenowego ubyli między innymi Witold Broda, Katarzyna Krupka, Daniel i Nela Brzezińscy, powołując własne inicjatywy poza terenem warmińskiej wioski, niezmienny skład zespołu tworzą już tylko Erdmute i Wacław Sobaszkowie, włączając do określonych projektów adeptów Innej Szkoły Teatralnej, wśród których zachodzi ciągła rotacja. Postępujący rozpad polskiego teatru antropologicznego pogłębia brak finansowania. Opisane już problemy Gardzienic czy Teatru Wierszalin znalazły dotkliwe odzwierciedlenie w niedawnej sprawie. Jesienią 2011 roku doszło do zwolnienia z pracy (po dwudziestu latach) w Centrum Edukacji i Inicjatyw Kulturalnych w Olsztynie ${ }^{13}$ członków Teatru Węgajty/ Projektu Terenowego: Erdmute i Wacława Sobaszków oraz Scholi Teatru Węgajty: Małgorzaty i Wolfganga Niklausów. Twórcy utrzymują się obecnie z dotacji, które otrzymują jako Stowarzyszenie Teatr Węgajty. Sytuacja ta oznacza dla nich tak naprawdę codzienną walkę o byt i niepewność jutra. Wymienione grupy teatru antropologicznego zaczynały jeszcze w PRL, kiedy były inne warunki działania. Demokracja przywróciła na przykład na Warmii kolędowanie, ale wolny rynek, czy też jak powiedziałby Michael J. Sandel: „społeczeństwo rynkowe”, zrobił swoje, czego efektem jest rozpaczliwa walka o przetrwanie. I o pieniądze, które w tym przypadku stają się kwestią moralną, zgodnie z rozumowaniem Adama Smitha i powołującego się na niego Michaela J. Sandela:

„Nie, pieniądze to coś więcej, zwłaszcza gdy proces kupna i sprzedaży wykracza poza sferę dóbr materialnych. Dopóki chodzi o określenie uczciwej ceny rynkowej za płaskie monitory, samochody czy filiżankę kawy, dopóty pozostają być może w miarę neutralne. Gdy jednak chodzi o dystrybucję dóbr niematerialnych, takich jak zdrowie, edukacja, środowisko naturalne, sprawiedliwość, obywatelstwo czy stosunki międzyludzkie, z pewnością pieniądze tę neutralność tracą" (Sandel, 2012).

W przypadku postępowania władz samorządowych wobec Teatru Węgajty etykę ludzkiego zachowania zastąpiła ekonomia.

Eugenio Barba wiele lat temu przewidywał, że grupy „trzeciego teatru” przetrwają tylko pod jednym z dwóch warunków: albo „jeśli poprzez uporczywą pracę znajdą swój własny obszar, szukając tego, co dla nich podstawowe, i skłaniając innych do szacunku dla tej odrębności”, albo „jeśli wejdą do kręgu teatru oficjalnego, akceptując prawa podaży i popytu, poddając się modnym gustom, podporządkowując się wymogom ideologów politycznych i kulturalnych” (Barba, 2003, s. 208). Czy skoro „ów własny obszar” odrzucit „trzeci teatr”, to czy pozostaje tylko drugie rozwiązanie?

13 Instytucja podległa kontroli Urzędu Marszałkowskiego Województwa Warmińsko-Mazurskiego. 


\section{Bibliografia}

Améry, J. (2007). O starzeniu się: Bunt i rezygnacja. Podnieść na siebie rękę: Dyskurs o dobrowolnej śmierci. Warszawa: Czytelnik.

Augustyn, Św. (2007). Księga XI. W Św. Augustyn, Wyznania. Warszawa: Znak.

Barba, E. (1993). Czterech widzów. Konteksty. Polska Sztuka Ludowa, (2).

Barba, E. (2003). Teatr: samotność, rzemiosło, bunt. (G. Godlewski, I. Kurz, \& M. Litwinowicz-Droździel, Tłum.). Warszawa: Instytut Kultury Polskiej.

Becker, H. S. (1971). Whose side are we on? W P. B. Horton \& G. R. Leslie (Red.), Studies in the Sociology of Social Problems. New York: Meredith Corp.

Beuys, J. (2005). Każdy artystą. W A. Mencwel (Red.), Antropologia kultury. Zagadnienia i wybór tekstów. Warszawa: Wydawnictwo Uniwersytetu Warszawskiego.

Blige M. (b.d.). „Więcej niż teatr”. Teatr Wiejski Węgajty - fenomen kulturowy i artystyczny (praca magisterska w UAM). Poznań.

Budziszewska, M. (2007). Czasy i opowiadania. O wspólnocie komunikacyjnej i narracyjnym trybie ujmowania doświadczenia u Paula Ricoeura. W B. Sierocka (Red.), Wspólnota komunikacyjna w teorii i praktyce (ss. 23-41). Wrocław: Oficyna Wydawnicza Atut.

Certeau, M. de (2008). Wynaleźć codzienność. Sztuki działania. (K. Thiel-Jańczuk, Tłum.). Kraków: Wydawnictwo Uniwersytetu Jagiellońskiego.

Foucault, M. (1987). Historia szaleństwa w dobie klasycyzmu. (H. Kęszycka, Tłum.). Warszawa: PIW.

Gadamer, H.-G. (1993). Prawda i metoda. Zarys hermeneutyki filozoficznej. (B. Baran, Tłum.). Kraków: Inter esse.

Geertz, C. (2005). Interpretacja kultur: wybrane eseje. (M. M. Piechaczek, Tłum.). Kraków: Wydawnictwo Uniwersytetu Jagiellońskiego.

Giard, L. (2008). Dzieje pewnych badań. Wprowadzenie. W M. de Certeau, Wynaleźć codzienność. Sztuki działania. (K. Thiel-Jańczuk, Tłum.). Kraków: Wydawnictwo Uniwersytetu Jagiellońskiego.

Głowiński, M. (Red.). (2004). Narratologia. Gdańsk: Słowo/Obraz terytoria.

Gombrowicz, W. (1986). Trans-Atlantyk. Kraków: Wydawnictwo Literackie.

Gombrowicz, W. (1994a). Ferdydurke. Kraków: Wydawnictwo Literackie.

Gombrowicz, W. (1994b). Iwona, księżniczka Burgunda; Ślub; Operetka; Historia. Kraków: Wydawnictwo Dolnośląskie.

Gombrowicz, W. (2002). Bakakaj i inne opowiadania. Kraków: Wydawnictwo Literackie.

Grotowski, J. (1990). Performer. W J. Grotowski, Teksty z lat 1965 - 1969. Wrocław: Wiedza o Kulturze.

Gurvich, G. (1987). Socjologia teatru. W W kręgu socjologii teatru na świecie. Wrocław: Zakład Narodowy im. Ossolińskich.

Janion, M. (1980). Odnawianie znaczeń. Kraków: Wydawnictwo Literackie.

Jasińska, M. (Red.). (2010). Teatr potrzebny: aspekty, konteksty, uwagi na zakończenie projektu Wioska Teatralna 2009. Węgajty: Stowarzyszenie „Teatr Węgajty”.

Jawłowska, A. (1988). Więcej niż teatr. Warszawa: PIW.

Kalevala - fragmenty niepisane (program spektaklu) (2000). Węgajty.

Kaźmierska, K. (1996). Wywiad narracyjny - technika i pojęcia analityczne. W M. Czyżewski, A. Piotrowski, \& A. Rokuszewska-Pawełek (Red.), Biografia a tożsamość narodowa (ss. 34 - 44). Łódź: Katedra Socjologii UŁ.

Kolankiewicz, L. (1991). Teatr zarażony etnologią. Konteksty. Polska Sztuka Ludowa, (3-4), 13-22. 
Kumaniecka-Wiśniewska, A. (2006). Kim jestem? Tożsamość kobiet upośledzonych umysłowo. Warszawa: Żak.

Kwiatkowska, 0. (2008). Obraz nieopisany. Wizerunek nowoosadników w perspektywie społeczności lokalnej (praca doktorska w IAIE PAN). Warszawa.

Limon, J. (2001). Między niebem a sceną: przestrzeń i czas w teatrze. Gdańsk: Słowo/Obraz terytoria.

LPR protestuje ws. Teatru Wierszalin. (2005, grudzień 21). wiadomosci.wp.pl. Pobrano 27 grudnia 2012 roku, z http://wiadomosci.wp.pl/kat,1342,title,LPR-protestuje-ws-teatru-Wierszalin,wid,8129702,wiadomosc. html?ticaid=1fc70

Lyotard, J.-F. (1997). Kondycja ponowoczesna. Raport o stanie wiedzy. Warszawa: Aletheia.

MacIntyre, A. (1996). Dziedzictwo cnoty. Studium z teorii moralności. Warszawa: PWN.

Marquard, 0. (1994). Apologia przypadkowości. Warszawa: Oficyna Naukowa.

Mikulska, A. (1999). Odszukiwanie zapomnianych form: Węgajty. W M. Sugiera (Red.), W stronę rytuału: od Yeatsa do Węgajt (ss. 223 - 236). Kraków: Księgarnia Akademicka.

Mościcki, P. (2008). Polityka teatru. Eseje o sztuce angażującej. Warszawa: Wydawnictwo Krytyki Politycznej.

Okopień-Sławińska, A. (2002). Litota. W J. Sławiński (Red.), Słownik terminów literackich (s. 286). Wrocław: Zakład Narodowy im. Ossolińskich.

Pyzik, T., \& Udalska, E. (Red.). (1987). W kręgu socjologii teatru na świecie. Wrocław: Zakład Narodowy im. Ossolińskich.

Ricoeur, P. (1995). Pamięć - zapomnienie - historia. W Tożsamość w czasach zmiany. Rozmowy w Castel Gandolfo (ss. 22-43). Kraków: Znak.

Ricoeur, P. (2002). Filozofia osoby. (M. Frankiewicz, Tłum.). Kraków: Wydawnictwo Naukowe Papieskiej Akademii Teologicznej.

Ricoeur, P. (2003). O sobie samym jako innym. (B. Chełstowski, Tłum.). Warszawa: PWN.

Ricoeur, P. (2008a). Czas i opowieść. Tom I: Intryga i historyczna opowieść. (M. Frankiewicz, Tłum.). Kraków: Wydawnictwo Uniwersytetu Jagiellońskiego.

Ricoeur, P. (2008b). Czas i opowieść. Tom II: Konfiguracja w opowieści fikcyjnej. (J. Jakubowski, Tłum.). Kraków: Wydawnictwo Uniwersytetu Jagiellońskiego.

Ricoeur, P. (2008c). Czas i opowieść. Tom III: Czas opowiadany. (U. Zbrzeźniak, Tłum.). Kraków: Wydawnictwo Uniwersytetu Jagiellońskiego.

Rosner, K. (2003). Narracja, tożsamość i czas. Kraków: Universitas.

Sandel, M. J. (2012). Kiedy wizja jest prowizją. Z Michaelem J. Sandelem rozmawiał Romain Leick (pierwodruk: „Der Spiegel” z 12 listopada 2012 roku). Forum, (51/52).

Schechner, R. (2006). Performatyka. Wstęp. (T. Kubikowski, Tłum.). Wrocław: Ośrodek Badań Twórczości Jerzego Grotowskiego i Poszukiwań Teatralno-Kulturowych.

Sobaszek, W. (1991). Ewolucja teatru wiejskiego? Konteksty. Polska Sztuka Ludowa, (3).

Sobaszek, W. (2009). DPS. Wspomnienia z przeszłości. W Wioska Teatralna. Teatr potrzebny - kontynuacje interwencje. Katalog festiwalu. Węgajty.

Sowiński, G. (Red.). (1993). Wokót rozumienia. Studia i szkice z hermeneutyki. Kraków: Wydawnictwo Naukowe Papieskiej Akademii Teologicznej.

Staniewski, W. (2009, listopad 11). Gardzienic Teatr Obiecany. Z Włodzimierzem Staniewskim rozmawiał Roman Pawłowski. Gazeta Wyborcza/Gazeta Stołeczna. Pobrano z http://warszawa.gazeta.pl/warszawa /1,95158,7244837,Gardzienic_Teatr_Obiecany.html 
Straś-Romanowska, M. (2010). Psychologia wobec małych i wielkich narracji. W M. Straś-Romanowska, B. Bartosz, \& M. Żurko (Red.), Psychologia małych i wielkich narracji. Warszawa: „Eneteia” Wydawnictwo Psychologii i Kultury.

Szekspir, W. (1987). Sen nocy letniej. (W. Tarnawski, Tłum.). Wrocław: Zakład Narodowy im. Ossolińskich.

Śliwonik, L. (1993). Życie teatralne - próba prognozy. FA-ART, (3-4).

Tarkowska, E. (1997). Ludzie w instytucji totalnej. Przypadek domów pomocy społecznej w Polsce. W E. Zakrzewska-Manterys \& A. Gustavsson (Red.), Upośledzenie w społecznym zwierciadle. Warszawa: Żak.

Taylor, C. (1996). Źródła współczesnej tożsamości. W E.-W. Böckenförde (Red.), Tożsamość w czasach zmiany. Rozmowy w Castel Gandolfo. (S. Amsterdamski, Tłum.). Kraków, Warszawa: Znak, Fundacja im. Stefana Batorego.

Teatr potrzebny - aspekty, konteksty, uwagi na zakończenie projektu Wioska Teatralna 2009. (2010). Węgajty.

Turner, V. (2005). Proces rytualny. W L. Kolankiewicz (Red.), Antropologia widowisk. Zagadnienia i wybór tekstów. Warszawa: Wydawnictwo Uniwersytetu Warszawskiego.

Waligórska, M. (2009). The Contemporary Klezmer Revival in Kraków and Berlin as a Jewish/non-Jewish Encounter (praca doktorska na European University Institute), Firenze.

Wioska Teatralna. Teatr potrzebny - kontynuacje - interwencje. Katalog festiwalu. (2009). Węgajty.

Wyka, A. (1993). Badacz społeczny wobec doświadczenia. Warszawa: Wydawnictwo IFiS PAN.

Wyspiański, S. (2001). Wesele. Kraków: Wydawnictwo Literackie.

Żmijewski, A. (2009). Co stało się raz nie stało się nigdy. Katalog wystawy. Warszawa: Zachęta.

\section{Strony internetowe:}

dpsjonkowo.pl, 14 stycznia 2008 - http://www.dpsjonkowo.pl/index.php?option=com_content\&task=view\&id=52\&Itemid=30 (dostęp: 7 maja 2012 roku).

Teatr Węgajty/ Projekt Terenowy - http://free.art.pl (dostęp: 2 grudnia 2012 roku).

Filmy:

Gombrowicz w DPS, reż. Emilia Hagelganz

Le monde diplomatique, reż. Emilia Hagelganz

Między aktami, reż. Katarzyna Lesisz i Alan Kępski

Węgajty. Wioska Teatralna, reż. Andrzej Klamt 


\section{Litotes situated in the grand narration of the anthropological theatre:}

a case study of Teatr Węgajty/Projekt Terenowy

Abstract: This article is an excerpt of the MA thesis: Litotes in the anthropological theatre's grand narrative. The case of Teatr Węgajty/Projekt Terenowy. It analyses the attitude of the anthropological theatre towards principles that constituted its foundation, such as the fascination with the traditional culture and work in the local community. The anthropological theatre's grand narrative is replaced by the small narrative of teatr potrzebny ('theatre of necessity'), which originates from the excluded, forgotten litotes. The paper provides documentation and an analysis of teatr potrzebny, taking the example of the work of Teatr Węgajty/Projekt Terenowy in a Social Welfare Home in Jonkowo.

Keywords: litotes, grand narrative, small narrative, anthropological theatre, Teatr Węgajty 